AUTHORS ONLINE: STRATEGIES FOR DIGITAL SELF-PROMOTION

\title{
Authors Online: Strategies for Digital Self Promotion
}

\author{
Master of Professional Communication \\ Ashley Regimbal-Kung \\ Ryerson University
}

Toronto, Ontario

August 2018 
AUTHORS ONLINE: STRATEGIES FOR DIGITAL SELF-PROMOTION

\section{Author's Declaration}

I hereby declare that I am the sole author of this MRP. This is a true copy of the MRP, including any required final revisions.

I authorize Ryerson University to lend this MRP to other institutions or individuals for the purpose of scholarly research.

I further authorize Ryerson University to reproduce this MRP by photocopying or by other means, in total or in part, at the request of other institutions or individuals for the purpose of scholarly research.

I understand that my MRP may be made electronically available to the public. 


\begin{abstract}
This paper explored strategies of digital self-promotion for authors online through the investigation of emerging, independent self-published writers. This research provides best practices through those strategies to assist self-published writers in furthering their public profile in digital marketing. The literature review provides context in the online self-publishing environment, connecting with the audience; encouraging collaboration (produsage); adapting to the shifting publishing marketplace through self-presentation strategies (branding), and; bolstering twoway communication (market sensing). It also provides the basis for coding selfpresentation themes in self-presentation. This research suggests that best practices can optimize the time that writers spend on marketing, not only to attract initial attention from publishers but at any stage in their career. This research gathers data and develops case studies of four self-published authors that use Wattpad, a social media platform for writers. It analyzes these authors' strategies for self-promotion and measures their effectiveness through the level of engagement elicited from their fans. It develops best practices from these strategies. This research finds that digital self-promotional activities are successful if they are creative, unique and develop a community of fan followers. It is especially effective when authors reflect the interests of their target audience. It was also found these strategies helped develop the author's branding for longterm effectiveness.
\end{abstract}


AUTHORS ONLINE: STRATEGIES FOR DIGITAL SELF-PROMOTION

\section{Acknowledgements}

This paper would not have been possible without the support of my partner, family and friends. 


\section{Table of Contents}

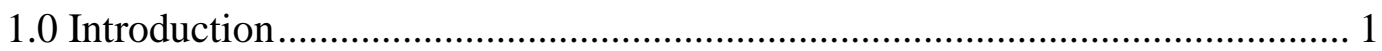

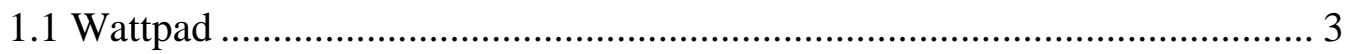

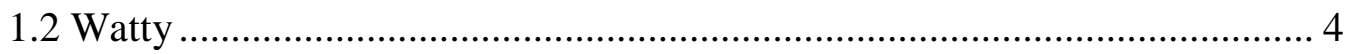

1.3 Wattpad Star ................................................................................... 5

1.4 Wattpad Ambassadors ........................................................................ 5

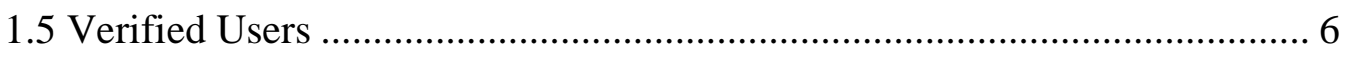

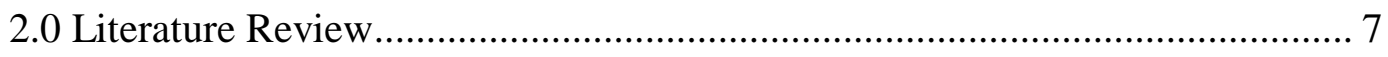

2.1 Produsage: Enabling an Active Audience ................................................ 7

2.2 The Shifting Publishing Marketplace ..................................................... 12

2.3 User Behaviour on Social Platforms like Wattpad................................ 15

2.4 Recognizing and Creating Opportunities for Conversation ...................... 18

2.5 Digital Self-Promotion and Branding .............................................. 21

2.6 Jones and Pittman's Self Presentation Taxonomy ................................... 24

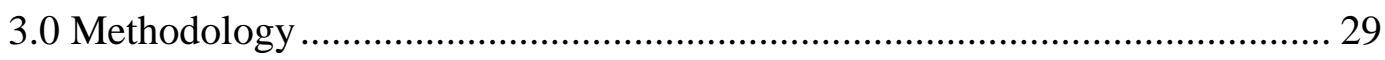

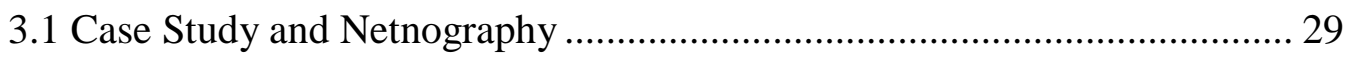

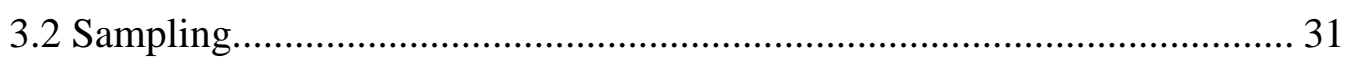

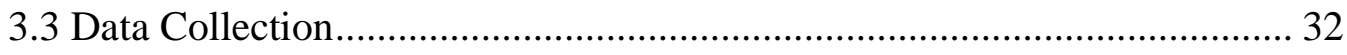

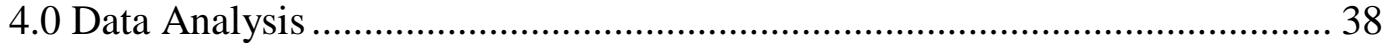

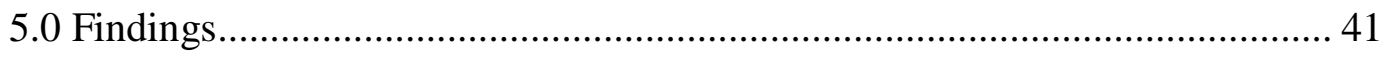

5.1 Patterns of Self-Presentation Strategies ................................................ 41

5.2 Strategies for Self-Branding on Wattpad ............................................. 42

5.3 Impact of Special Events on Engagement ............................................ 43

5.4 Impact of Author Reply Frequency on Fan Behaviour ............................ 46

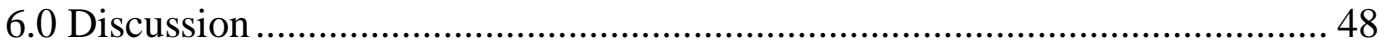

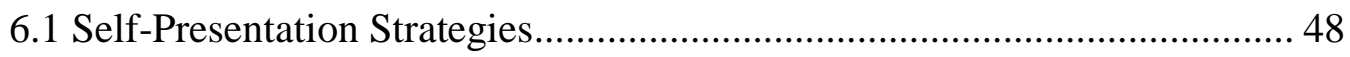

6.1 Strategies for Self-Branding on Wattpad .......................................... 51 
6.2 Impact of Special Events on Engagement .......................................... 56

6.3 Impact of Author Reply Frequency on Fan Behaviour ............................. 56

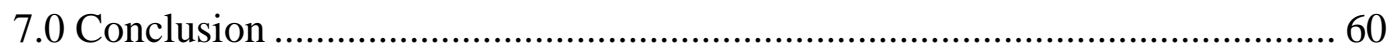

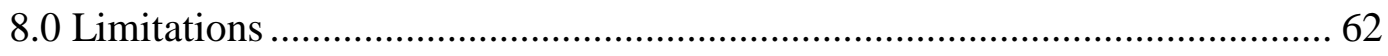

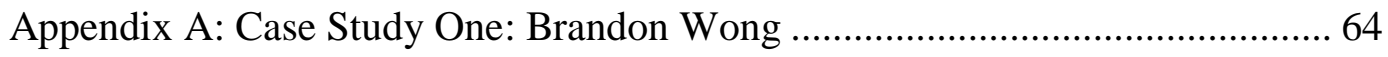

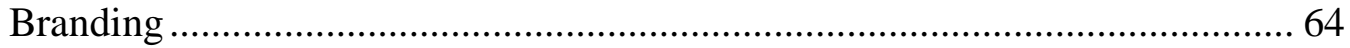

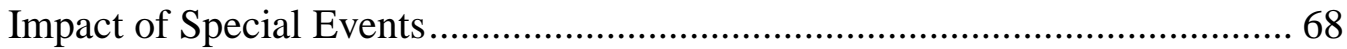

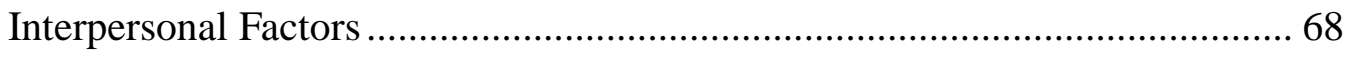

Appendix B: Case Study Two: Claudia Tan .................................................. 70

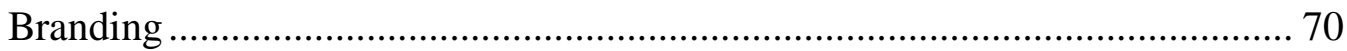

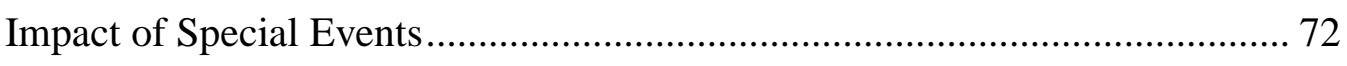

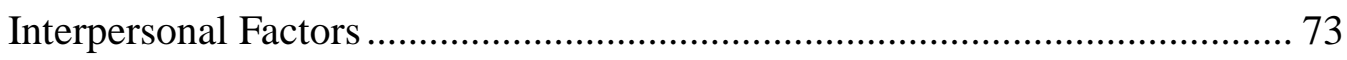

Appendix C: Case Study Three: A.V. Geiger .................................................. 76

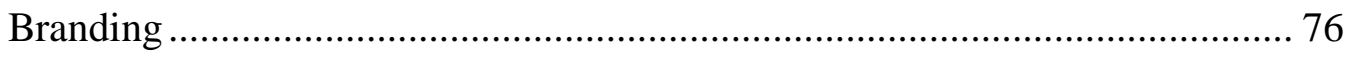

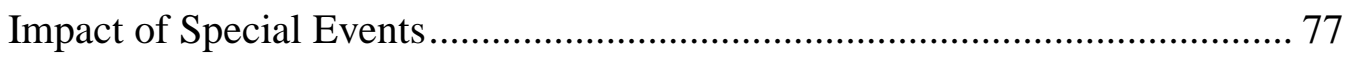

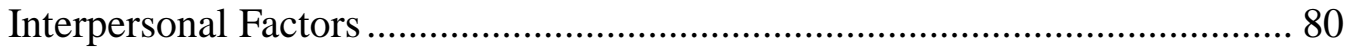

Appendix D: Case Study Four: Shaun Allen ................................................. 81

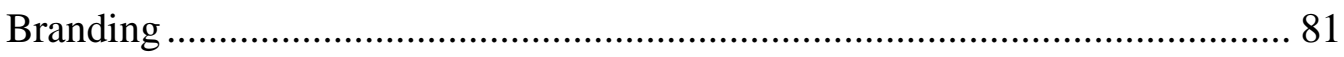

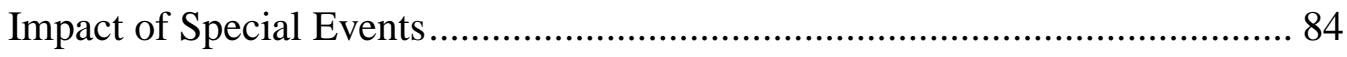

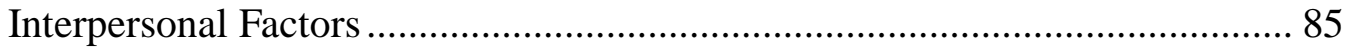

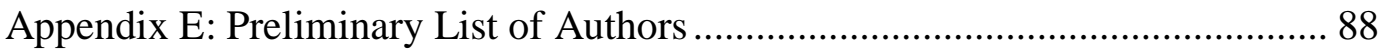

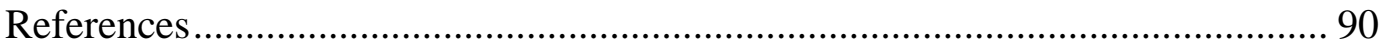


AUTHORS ONLINE: STRATEGIES FOR DIGITAL SELF-PROMOTION

\section{List of Tables}

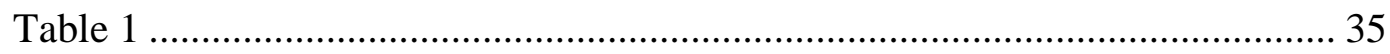

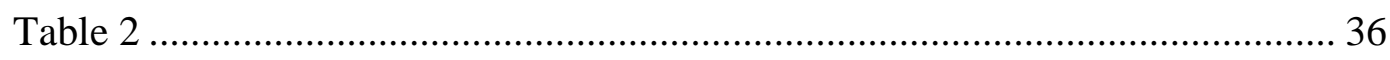

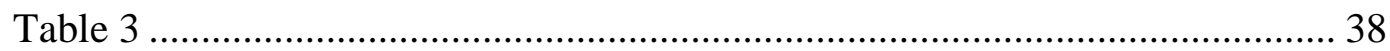

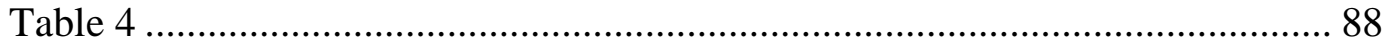


AUTHORS ONLINE: STRATEGIES FOR DIGITAL SELF-PROMOTION

\section{List of Figures}

Figure 1: Author Avatars (left to right): A.V. Geiger, Brandon Wong, Claudia Tan and Shaun Allen ................................................................................... 55 


\subsection{Introduction}

With the explosion of technology and the internet, the world of writing and self-publishing has been revolutionized because the internet allows authors to self-publish work (Bold, 2016; Flahive, 2017; Kaplan \& Haenlein, 2010).

Publishers, once the gate keepers, are no longer the only means for authors to publish (Bold, 2016; Flahive, 2017; Pham, 2010). Indeed, the opportunity to pen, self-publish and interact with the audience has never been greater (Bold, 2016; Flahive, 2017) and business is booming. In the United States of America (U.S.A.) alone self-published works had "increased by an estimated 442\% between 2007 and 2013" (Flahive, 2017, p. 26). Along with this increased reach and connectivity comes a demand for strategies to support authors' efforts of digital self-promotion and audience engagement to make their name known (Flahive, 2017).

This research paper explores the digital self-promotion strategies of four self-published writers that use the social media platform, Wattpad, to form case studies. The purpose of this paper is to develop a list of best practices from those strategies. This paper asks what digital self-promoting strategies helped those online writers to further their public profile. It is to optimize the time writers spend on self-promotion, not only to attract initial attention from publishers but at any stage in the promotional process. 
This study follows various theories involving the author, audience and environment of self-pushing including: produsage, the shifting publishing marketplace, self-presentation, two-way communication and collaboration. These theories provide an understanding of self-presentation and self-promotion strategies that author's have employed online.

This research paper is divided into eight sections. Chapter 2 begins with a literature review that introduces readers to the trend of online authors, connecting with the audience and encouraging collaboration (produsage). It also discusses adapting to the shifting marketplace through self-branding and self-presentation strategies. This section also describes the coding process (taxonomy of attributions) that I use in developing and analyzing the case studies.

Chapter 3 outlines the methodology and data collection used to develop the case studies. It discusses why this research method was chosen. It also outlines the steps I took to ensure thorough and sound research methods and how the sampling was selected and how the data was collected.

Chapter 4 outlines how the data was analyzed. It outlines the coding schemes that include Jones and Pittman's Taxonomy of attributions that are shaped by self-presentation strategies as introduced in the literature review. These schemes are applied to: 1) interactions that generated a follow-up response from commenters, and; 2) author posts. 
AUTHORS ONLINE: STRATEGIES FOR DIGITAL SELF-PROMOTION

Chapter 5 documents the findings which are divided into three main parts:

1) Strategies for Self-branding on the Literary and Social Platform Wattpad; 2)

Impact of Special Events on Engagement, and; 3) Impact of Author Reply

Frequency on Fan Behaviour.

Chapter 6 discusses the findings on each of the three parts outlined in

Chapter 5.

Chapter 7 concludes the research paper with recommendations for future research and offers concluding remarks.

Chapter 8 identifies the limitations of the study.

This paper begins with a brief discussion of Wattpad to provide a contextual background of the social platform where the data was collected and why it was used. It then follows with definitions of platform specific jargon (e.g. Watty, Wattpad Star) that are used throughout the case studies in my report that deserve mention.

\subsection{Wattpad}

Wattpad is a social and digital platform founded in Toronto in 2006 by Allen Lau and Ivan Yuen (Bold, 2016; wattpad.com). It has a global community that has grown to 65 million people (wattpad.com). Wattpad offers user-created content, novels and short stories, for users to read at no cost. It also allows authors 
AUTHORS ONLINE: STRATEGIES FOR DIGITAL SELF-PROMOTION

a free platform to self-publish, create and share reading lists, and participate in writing contests. For publishers, Wattpad is a source of literary talent, where publishers or agents (traditional gatekeepers), can "scout the next Anna Todd or Beth Reekles (two authors that have been published by traditional publishers as a result of their popularity on Wattpad)" (Bold, 2016). As their homepage states, "Wattpad gives people from around the world access to an audience of millions and connects them with content they can't find anywhere else" (Wattpad, 2017).

Their mission statement articulates its' aim to create a democratic platform to cater to many user needs, but particularly for author promotion: "You can discover the things that speak to you or choose to create them from scratch. It's the freedom to express yourself with an authentic voice, and the knowledge that you will be heard" (Wattpad, 2017). Authors who choose to contribute work can do so incrementally, for example only a chapter at a time, and may upload works for a limited time or even choose to leave draft versions on the site after formal publication (wattpad.com).

Consumers play an important role as their actions may affect the algorithms that impact visibility for writers. Their participation on Wattpad has led to professional success through increased visibility for many authors (Bold, 2016).

\subsection{Watty}


A "Watty" is an award granted by Wattpad. The recipients of this award are chosen using a combination of "data analysis and overall editorial scores" (Wattpad, 2017). There are various categories including: The Originals, best described as exploratory works that defy traditional genre-based definitions; Riveting Reads, which can be described as thrillers; The Breakthroughs, works that "caused a stir" or generated a lot of conversations on Wattpad; The Newcomers, works from authors who first published works on Wattpad either on or after September 1, 2016; The Storysmiths, which marks a commitment to the craft of storytelling; and The Tap Award, for a particular type of story that uses solely text messages to convey a narrative where users "tap" literally to generate the next message.

\subsection{Wattpad Star}

The Wattpad Stars program is how Wattpad support successful writers. As Wattpad states, "We recognize the hard work of our Wattpad Stars and connect them with new opportunities to take their writing to the next level" (Wattpad, 2018). The term "next level" refers to networking and professional opportunities with publishers and film producers.

\subsection{Wattpad Ambassadors}

The Wattpad Ambassadors are a group of users who volunteer with Wattpad to support the community. They help users, assist in organizing the story 
categories and languages, moderate Wattpad Clubs, and host community initiatives. The Wattpad Ambassadors also assist in answering general questions about Wattpad, how Wattpad works, and up-to-dates users on news (Wattpad, 2018).

\subsection{Verified Users}

Wattpad uses accounts are verified to let readers and writers know that a person is truly representing themselves. This program is currently not open to the public. Wattpad will only verify specific accounts where necessary to their discretion. However, as Wattpad notes, "verified accounts are not designed to confirm a writer's copyright" (Wattpad, 2018). This is important as this paper assumes the self representation of the authors in this study.

This paper will now discuss the community of online authors and their audience, adapting to the shifting marketplace, user behaviours and recognizing and creating opportunities to provide context of the online writing environment. It then discusses different branding and self-presentation theories including the taxonomy of attributions through the literature review. 


\subsection{Literature Review}

\subsection{Produsage: Enabling an Active Audience}

Online communities have emerged as a social phenomenon since the evolution of the internet as a communication medium (Preece, 2000). Created for purposes ranging from knowledge-sharing to e-commerce, these communities can thrive or fizzle. It is important to understand the social and technological aspects of these communities to understand effective design and community-management practices. The online communities are facilitated by users that contribute content known as “crowd-sourcing” (Bruns, 2008).

Crowd-sourcing content is a practice that can be seen across popular online communities such as Wikipedia, Instagram, Twitter, and Wattpad. Active or passive participation in communities that rely on crowd-sourced content and editorial activities enables participants to become both a producer and user. This is shortened into the portmanteau "produser" (Bruns, 2007, 2008).

Produsage does not necessarily imply to connect to audience (a correction to the header for this section therefore seems to be required). Rather, it empowers audience to also become producers (2018). Bruns states that produsage is often a social, community-driven practice with hierarchies of organization and ad hoc principles of governance that help them function smoothly: 
The question of how to assess personal merit, how to award, maintain, and withdraw indicators of communal reputation, and how to ensure that such indicators can be trusted by others inside and beyond the community are paramount in his investigation of reputation and trust in collaborative spaces (Bruns, 2008, p.313).

Indicators of merit may pervade a system (e.g. stars awarded by Wattpad), but often can be limited to a single page within a larger site (Wikipedia is one example of this in practice).

The limited nature of online platforms can lead to conflict and hostility between users due to the lack of social cues typically present in face-to-face interactions, such as tone of voice or facial expressions (Baym, 2017). Most social platforms now include elements that can be used to help augment the discussion including emojis and social shorthand to make up for these limitations (e.g. LOL - laugh out loud - is often used to underscore humour in a comment that might be mistakenly read in a negative tone).

Bruns (2008) states that managing interpersonal pitfalls inherent in social networks in digital spaces is possible through platform design and integration of behaviour-management techniques that evolve over time. Bruns discusses four key principles of produsage: open participation, with communal evaluation; fluid hierarchy with ad hoc meritocracy; unfinished artifacts with continued processes; and common property with individual rewards (2008). 
AUTHORS ONLINE: STRATEGIES FOR DIGITAL SELF-PROMOTION

The principle of open participation and communal evaluation refers to the need to draw upon the broad range of skills and available knowledge (Bruns, 2008). This is contributed in varying degrees by users. Those contributions deemed worthwhile will be further built upon as the process continues.

The principle of fluid heterarchy and ad hoc meritocracy is based on a principle described by Michel Bauwens (2005) as equipotentiality: while participants in produsage may not have equal knowledge or skills to contribute, they each have an equal opportunity to make a worthy contribution (p.1; Bruns, 2008, 2009). As Bruns (2009) notes:

...the interplay of contributors and contributions, this ongoing evaluation, re-evaluation, and repositioning of users on the basis of their latest contributions, is a highly changeable network of power relations which is best described as a fluid heterarchy and an ad hoc meritocracy (p. 7).

This process allows leaders to emerge based on standing within a community and allows for that standing to wax and wane depending on the individual's continued participation and contribution. It is therefore in a constant state of flux.

Unfinished artefacts and continuing process allows for varying degrees of participation, inviting both large and small contributions from participants and the fluctuating levels of participation and hierarchies, all projects in this model are ongoing (Bruns, 2008). To ensure that the project continues to develop, contributions are assessed by the group after they are made through ad hoc meritocracy (Bruns, 2008). The principle of community evaluation means that 
negative contributions will be discovered quickly. Negative contributions will also affect the reputation of the individual associated with them, causing other participants to view their future contributions through a more critical lens (Bruns, 2008, 2009).

The principle of common property and individual rewards assumes content created through produsage will continue to be available to future participants just as it was available to those who have already contributed (Bruns, $2008,2009)$. Any attempt to monetize the projects that arise from produsage must be limited to what is seen as within the rules of the community (Bruns, 2008, 2009.

Those hoping to cultivate a community for produsage for work they intend to publish for profit are faced with the difficulty of assessing contributions, navigating shifting hierarchies and ultimately finding a way to publish content that honours past relationships by allowing access to content (Bruns, 2008, 2009). It is also difficult to sell a product that relies on the unpaid contributions of participants, to say nothing of the potential for backlash if the work draws heavily on the work of others, such as fanfiction which will be discussed in the following section.

Scholarship on the shifting "publishing marketplace" (Wilkins, 2014, p. 67) focuses on effective uses of social media for many platforms including 
AUTHORS ONLINE: STRATEGIES FOR DIGITAL SELF-PROMOTION

Twitter, Facebook and Instagram. Bold (2016) focuses on Wattpad. While Wattpad's design is uniquely suited for digital publication and distribution of written work, with $90 \%$ of users consuming content created by the other $10 \%$ (Wattpad, 2017), it remains a social platform, subject to the many pitfalls and quirks of social platforms, including the need to slowly build a following from the ground up. This is done through the slow process of direct reciprocity in the form of likes for likes, votes for votes and exchanging positive comments for art, to give a few examples of common behaviours referred to by Bold (2016). Only after an author has achieved a great deal of notoriety might they hope to be freed from the slow process of individual interactions (Davies, 2017) since at a certain point the built-in algorithms grant the most liked, saved, and up-voted material more visibility.

For better or worse, given the tendency for authors to maintain a presence on many platforms, one platform may not be enough to generate enough audience or build a community. Integration of several platforms may be necessary to develop the kind of visibility required for recognition and effective communication about key moments, such as an award nomination or a new release. (Davies, 2017)

For Kinberg (2014), the development of a community demonstrates an author's cultural capital, that is their relative importance necessary in the modern 
AUTHORS ONLINE: STRATEGIES FOR DIGITAL SELF-PROMOTION

publishing world to get noticed by established publishers. Many platforms can be integrated in an outreach strategy that can loop in the community and encourage them to interact, to vote or to comment (Kinberg, 2014).

\subsection{The Shifting Publishing Marketplace}

With the advent of social media, readers are enabled to become more participatory and interactive-shifting the "author-reader dynamic" (Bold, 2016; Murray \& Squires, 2013). Boyd (2018) calls this the context collapse as it allows various actors to co-exist in a social context where once they were separate (Bold, 2016; boyd, 2018). Publishers and authors alike can communicate with themselves and readers on social media. This can build author and book related communities (Bold, 2016). This can lead to increased sales but also allows insights into the readers needs. The rise of social platforms as Wattpad attest to the demand for authorship without publisher intervention (Bold, 2016).

In fact, collaboration, co-creation and participatory strategies are increasingly important in the shifting online environment for the digital publishing marketplace (Boyd, 2008; Bold, 2016: Cerand, 2011; Flahive, 2017; Gulbrandsen \& Sine, 2011; Kaplan \& Haenlein, 2010; Kinberg, 2014; Rinzler, 2011; Wilkins, 2014). Digital communities that revolve around literature thrive on active participation and collaboration from readers (Bold, 2016) and author-fan interactions (Wilkins, 2014). It follows that on a social platform as Wattpad it 
AUTHORS ONLINE: STRATEGIES FOR DIGITAL SELF-PROMOTION

may be beneficial for authors to capitalize on the self-directed nature of the platform. This is to create more opportunities for fan commentary and reward their participation with positive feedback. Indeed, literary communities like Wattpad also function as market-sensing tools for authors and publishers. Marketsensing is "a customer-oriented approach to making use of market research data" (Kinberg, 2014, p. 48). The data is best collected "through continuous contact with the market" (Heusinkveld, Benders \& ven den Berg, 2009, p. 509). In the literary world, websites like Wattpad are perfect market-sensing tool (Kinberg, 2014).

Kinberg argues for the integration of promotion and market-sensing for authors in the changing landscape of the publishing world, citing the increasing expectation for new authors to take on marketing and promotional tasks (2014). Market-sensing can provide helpful insight for the author not only at the initial stage (such as choosing or not to continue a series or to begin a new one) but also at virtually every step of product development, including launching, promotion and sale (Kinberg, 2014). For authors this could mean gathering insight even during the creative process, while developing plot or during the publishing process (e.g. when deciding to produce a Kindle or paperback version) (Kinberg, 2014). 
AUTHORS ONLINE: STRATEGIES FOR DIGITAL SELF-PROMOTION

Indeed, the traditional notion of publishing is seen as hindering the creative process (Murray \& Squires, 2013). For some publishers, this has meant developing their own self-publishing path and scout for talent among selfpublishing platforms (Murray \& Squires, 2013; Phillips, 2014). However, this has not always been successful. For example, the demise of HarperCollins' platform Authonomy, the unsuccessful Penguin Random House's Author Solutions, and HarperCollins' decision to sell the teen platform Inkpop to a competitor as well as the commercialization of fan fiction to a competitor suggest that that the participating creative cultures do not work under traditional publishing structures (Bold, 2016; Page, 2015).

Many publishers now scout for the next best seller concentrating on marketable authors (Bold, 2016). Consequently, mid-list and first-time authors suffer. Bold (2016) makes note that "contemporary authorship is characterized by the polarity of author's earnings" (p. 4). That is, the small celebrity author can command large advances while new forthcoming authors cannot.

Despite this, authorship is very much alive, and the digital environment enables authors to contribute to the "exponential growth of digital literary content" (Bold, 2016, p. 5). One outcome of the digital shift is that "traditional publishers are no the sole longer the gatekeepers of written culture" (p. 5). Although self-publishing can reflect the traditional publishing marketplace, "a 
AUTHORS ONLINE: STRATEGIES FOR DIGITAL SELF-PROMOTION

new generation of writers are building audiences, on social platforms, through direct engagement with readers even before publishing through platforms such as Amazon/Kindle Direct" (p. 5). The "popularity of Wattpad" is an example of an influential, social-media savvy generation entering the publishing market (Bold, 2016, p. 5).

\subsection{User Behaviour on Social Platforms like Wattpad}

Kaplan and Haenlein (2010) suggest classifying user behaviours on social platforms into a taxonomy based on their unique qualities. User Generated Content (UGC) must be published in a "publicly accessible website or on a social networking site to a select group of people"; second, it must show creativity; and finally, it must be "created outside of professional routines and practices" (Kaplan \& Haenlein, 2010, p. 61). For a platform to be called "social media", it also must fulfill two key elements: social presence, which is related to media richness, and social processes such as self-disclosure and self-presentation (Kaplan \& Haenlein, 2010). Kaplan and Haenlein (2010) assert that social presence is impacted by two factors: intimacy, interpersonal versus mediated through technology; and immediacy, asynchronous (e.g. email) versus synchronous (e.g. live chat or telephone), of the medium. This presence will be lower for mediated intimacy than interpersonal and for asynchronous immediacy than synchronous communications (Kaplan \& Haenlein, 2010). The latter poses a challenge for 
AUTHORS ONLINE: STRATEGIES FOR DIGITAL SELF-PROMOTION

those communicating through low-media-rich, asynchronous social media platforms like Wattpad (Kaplan \& Haenlein, 2010).

The concept of user self-presentation is also integral to the social dimension of social media (Kaplan and Haenlein 2010). The concept states that individuals - in this case, users - tend to seek control of the impression they give to others (Kaplan \& Haenlein, 2010). This is done to influence their impression, to gain rewards or to create an impression that is consistent with one's own selfperception or identity (Kaplan \& Haenlein, 2010). For example, if a person is wearing fashionable clothing in their avatar, they wish to appear trendy to others.

A user's projected persona creates context that users will draw on to understand what they read and see. The importance of creating a cohesive identity is important for many users of social platforms, including writers (Wilkins, 2014). When actions and words are harmonious it helps to build trust with the target audience.

Kaplan and Haenlein's taxonomy of social media types helps to understand the opportunities and pitfalls of Wattpad as a platform (2010). A combination or hybrid of the platforms covered in their taxonomy, include: 1) collaborative projects (e.g., Wikipedia), where the "joint effort of many actors leads to a better outcome than any actor could achieve individually" (Kaplan \& Haenlein, 2010, p. 62); 2) blogs, which display date-stamped entries in reverse- 
AUTHORS ONLINE: STRATEGIES FOR DIGITAL SELF-PROMOTION

chronological order, managed by one person only but allow for interaction through comments; 3) content communities, (e.g. BookCrossing, Goodreads) aimed to facilitate a sharing of content between users, a function that is relied upon by commercial organizations; and, 4) social networking sites (e.g., Facebook) where users are enabled to connect by creating personal information profiles and inviting others to connect (p. 63). These media types and subsequent issues deserve further elaboration.

Collaborative projects on Wattpad are developed through fan commentary at the outset. The "group-based collection and rating of... media content" (Kaplan \& Haenlein, 2010, p. 63) allows for authors to make changes to their works based on feedback from their followers, for one, while at other times authors co-write works or collections of works. Kaplan and Haenlein (2010) illustrate the lack of professionalism that can lead to misinformation or conflicting information.

Wattpad can also be called a blog because the site features conversation boards with date-stamped entries and author-generated posts that invite commentary from their followers (Kaplan \& Haenlein, 2010). Blogs carry another set of issues, such as the potential for unwanted commentary. WordPress, that also functions as a content community through its content management and blogging system in that users create reading lists comprised of works found on the site in addition to other common practices like writing contests and anthologies 
AUTHORS ONLINE: STRATEGIES FOR DIGITAL SELF-PROMOTION

(WordPress, 2018). The issue inherent on these blogging sites is the problematic nature of sharing content derived from copyrighted material, which Jones (2014) highlights as a growing issue within fanfiction. Finally, Wattpad also functions as a social networking site that allows users to connect with each other through the creation of personal profiles (Kaplan \& Haenlein, 2010).

Wattpad combines the functions of many types of platforms (2018). As a result, Wattpad users would stand to benefit from an understanding of the unique challenges of the platform to develop strategies in overcoming them (Kaplan \& Haenlein, 2010).

\subsection{Recognizing and Creating Opportunities for Conversation}

Approximately 30 years ago, Grunig predicted the growing need for twoway communications $(1984,2006)$. He argued that two-way symmetrical communications would be the most effective communication strategy between an organization and its public for building and maintaining relationships (Grunig, 2006). He further indicated the need to build on that practice with other techniques to draw publics together into a community.

Grunig's theoretical structure focused on the "strategic management role of public relations" (Grunig, 2006, p. 153). The framework proposed was not meant to subvert other theories but to work alongside them as one lens that practitioners can use to understand and guide public relations to produce the 
AUTHORS ONLINE: STRATEGIES FOR DIGITAL SELF-PROMOTION

greatest value. Grunig's situational theory has a basis in two concepts: the psychological theory of cognitive dissonance, and information seeking practices (2006). Cognitive dissonance theory explains a tendency in human behaviour to choose things that reinforce one's perception of self (Grunig, 2006). Simply put, people tend to curate the messages they seek out, favouring messages that echo their own prejudices and biases (Grunig, 2006).

Further to this are information seeking practices (Grunig, 2006). People tend to seek out relevant information when they have an economic decision to make. This is a tool that can be used to segment stakeholders into publics. Organizations can use this to better understand their publics and develop effective relationships with publics on either end of the passive-active spectrum.

Grunig's and Hunt's organizational theory of communications includes four frameworks: press agentry, defined as one-way and self-promotional; public information, one-way and didactic; two-way asymmetrical, which incorporates some opportunities for communication, typically limited to the press; and twoway symmetrical, where opportunities are available to learn about an organization or individual, ask questions and receive answers and see those answers reflected in the actions of the organization or individual (1984). This theory features the tendency for organizations to favour what they have done in the past due to lack of knowledge: one-way form of communication, such as traditional marketing, 
publicity, and media relations (Grunig, 1984, 2006) rather than two-way symmetrical public relations, even when the situation was ideal for it. An ideal situation requires management to value the participation of publics and a participative public culture. An example of this is the Wattpad platform (Davies, 2017).

Indeed, the participative culture of Wattpad users has many benefits for authors, primarily facilitating crowdsourcing information (Davies, 2017). By design, Wattpad is a low-cost route to understanding how well a chapter meets the expectations of readers. This allows the consumer to shape the final product and for the writer to take (or leave) their feedback, or to speak to it directly (Davies, 2017).

Grunig's (2006) model of the shift in public relations describes an ongoing mutually effective relationship. For example, an organization (or author) proactively generates goodwill through encounters by sharing information (e.g. notifications of opportunities or events that may interest them) that holds value to the publics and are not directly linked with economical ends (Grunig, 2006). The return on investment for public relations can be difficult to gauge. This can be resolved by segmenting an organization's publics into discernable groups that can lead to more targeted and more effective strategies for the future. It also has 
AUTHORS ONLINE: STRATEGIES FOR DIGITAL SELF-PROMOTION

effects on the perception of reputation, brand, image or identity which is the main goal of advertising and marketing practices.

The cultivation of online communities through social media requires recognizing and using opportunities for communication. Bold (2016) analyzes the way different types of authors, such as established authors like Margaret Atwood, celebrity authors and emerging authors, use Wattpad to take advantage of the democratising influence of social media. Creating opportunities for interactions with fans through communication, such as posts or comments, is a strategy for success. However, authors can go further to capture the public's attention through creative marketing campaigns that require out-of-the-box thinking (Flahive, 2017) and by using language that reflects that of the fans (Boyd, 2008).

\subsection{Digital Self-Promotion and Branding}

Digital self-promotion is essential for success in the modern publishing industry for emerging and established authors alike (Cerand, 2011; Flahive, 2017; Kinberg, 2014; Wilkins, 2014). This is not to say that digital self-promotion is a universally effective medium for selling products. There are many ways it can hurt, rather than help authors as they search for their audience (Morrison, 2012). Understanding what strategies have worked and failed across platforms can teach writers and inform their social practices giving them the ability to mindfully focus on strategies that will give them the highest rate of return on investment 
AUTHORS ONLINE: STRATEGIES FOR DIGITAL SELF-PROMOTION

Studies of effective use of social media platforms for author selfpromotion have shown that some strategies are very effective across platforms. These strategies include community cultivation and management through their brand (Muzellec, Lynn, Lambkin, 2012). Branding has traditionally been defined as a name associated with a physical product as an "identifying symbol or word that distinguishes it from its competitors" (Muzellec, Lynn, Lambkin, 2012, p. 1).

Today, the term branding has evolved to what is known as self-branding (Gandini, 2016). This concept began in the 1990s and evolved from selfimprovement methods implemented for corporate success. This "was originally conceived as a process of self-packaging of identity substantially delinked from skills, motivations and interests and centred on the crafting of a unique and authentic image to be sold on the labour market" (Gandini, 2016, p. 3). Whereas branding traditionally referred to differentiation of a product, increasingly people saw the benefit of packaging themselves, not in what they can do in a professional sense, but socially (Gandini, 2016).

Dissonance is a challenge when developing a cohesive brand that communicates across multiple touchpoints (Gyrd-Jones, Merrilees, \& Miller, 2013). In order for a brand to seem authentic to their audience, brand image, developed through communications, must be consistent. In order for visual differentiation to be successful, many corporate brands focus on "visual cohesion, 
AUTHORS ONLINE: STRATEGIES FOR DIGITAL SELF-PROMOTION

including logos, vision and brand essence statements and slogans" (Gyrd-Jones, et al., 2013, p. 578).

The cultivation of a persona through self branding can be controlled by careful curation of identity projected on social media (Boyd, 2008). This should be done with utmost care as the coarseness of digital bodies may lead to misinterpretation of the identity presented by an individual (Boyd, 2008).

Yet identity can be fostered to create what is known as fan-desire, or the desire to occupy the same space as a favorite author (Bold, 2016). As Bold argues, an author's brand through its association with quality of work can "develop a loyalty between author and fan" (Bold, 2016, p. 9). This combined with the ethos of author reputation, defined as a combination of their identity and standing and personal presence, can influence the behaviour of online fancommunities.

In fact, fan-desire implies a hierarchy between author and fan. This hierarchy conforms to Bruns' functional definition of hierarchies of participants in digital produsage (Bruns, 2008). Baym indicates the influence of hierarchies in mediated environments where some individuals (those with more social power, and in the case of Wattpad, this would be the authors with higher social standing) have more influence on behaviour through "regulating behavioural standards within group contexts" (2017, p.90). This indicates the potential influence of 
AUTHORS ONLINE: STRATEGIES FOR DIGITAL SELF-PROMOTION

authors on the groups that form around them via the brand and persona they cultivate (Baym, 2017).

The changing landscape of the publishing industry necessitates a change in the concept of the role of the writer (Wilkins, 2014). Cultivating a writing practice that includes self-promotion efforts allows writers to build and engage with their community of fans directly (Bold, 2016), allowing for creative marketing (Flahive, 2017), positive and consistent communications (Cerand, 2011), and cost reduction through self-publishing online and free distribution (Rooney, 2014).

Scholars have investigated best practices of online community cultivation and dialogue, but more information is required for real-world application of these concepts (Wilkins, 2014). Wattpad's platform design provides a unique opportunity to investigate the use of discreet elements (Boyd, 2008; Bold, 2016), that offer an opportunity to be more targeted with research-based recommendations.

\subsection{Jones and Pittman's Self Presentation Taxonomy}

To streamline the discussion of outreach tactics in the realm of professional communications, Jones and Pittman (1982) developed a theory of "strategic self-presentation" (p. 235). This involves the shaping responses to create in specific others an impression that is for one reason or another desired by the actor" (p. 233). Self-presentation is defined as "those features of behavior 
AUTHORS ONLINE: STRATEGIES FOR DIGITAL SELF-PROMOTION

affected by power augmentation motives designed to elicit or shape others' attributions of the actor's disposition" (Jones \& Pittman, 1982, p. 233). Selfpresentation involves "linking power motives" to "strategic resources" (p. 235). This linkage is shaped by "cognitive process in the self-presenting actor and further shaped by evaluative or moral constraints" (p. 235). The interaction of "motive, cognition, and morality determine the choice of self-presentational strategies" (p. 235). The goal is the "augmentation or protection of the strategist's power to influence and control his social environment" (Jones \& Pittman, 1982, p. 250). The defining feature of each is the attribution sought by the strategist. This forms a taxonomy of attributions. From these, Jones and Pittman derived five classes of self-presentation strategies to reflect the variety of impression management behaviours. They are: ingratiation, intimidation, self-promotion, exemplification, and supplication (Jones \& Pittman, 1982).

The ingratiation strategy is used to illicit "positive emotions associated with affection" to attain its goal (p. 259). That is, individuals engage in direct reciprocity, do favors or use flattery to seem likeable (Jones \& Pittman, 1982). The efforts to be liked are raised when the actor is in a dependent or low-power position. In fact, the sincerity of compliments or flattery must be perceived as sincere. Therefore, "establishing credibility is a major task for the ingratiator" (p.259). 
AUTHORS ONLINE: STRATEGIES FOR DIGITAL SELF-PROMOTION

The strategy of intimidation uses a threat and the "manipulation of fear" (p. 259). This strategy uses credibility to be effective although this can be selfdefeating. Subtle forms of intimidation such as affection and respect may shape the behaviour and lead to "omissions or diversions" (p. 259). Typically, intimidators are in positions of "high power relative to their targets" (p. 259). In cases where there is a "clear differential power intimidation breeds ingratiation" and therefore provides the intimidator with misleading feedback (p. 259).

The strategy of self-promotion emphasizes competence and respect rather than affection (Jones \& Pittman, 1982). That is, individuals would highlight their accomplishments to be perceived as competent (Jones \& Pittman, 1982). One feature is evidence regarding ability. The danger arises in false claims in which the "self-promoted may be discredited" (p. 259). However, the lines of interpretation from performance to attributed ability are generally weak enough to allow for strategic maneuvering (Jones \& Pittman, 1982). These "selfhandicapping strategies" are useful for deceiving oneself as they can be important in positioning one's self-presentations before an audience (p. 259).

The fourth strategy, exemplification, ranges from manipulations of slanderers and religious leaders to those serving a moral role, for example, a parent or teacher (Jones \& Pittman, 1982). Employing this strategy involves exemplifying virtue or worthiness that has diverse implications for the strategist. 
AUTHORS ONLINE: STRATEGIES FOR DIGITAL SELF-PROMOTION

A consequence of this is the pressure on the exemplifier may be the use of "timeouts" or the separation of "on-stage from back-stage performances" (p. 258). In this case, the exemplifier would maintain a moral stance in front of an audience and another in private (Jones \& Pittman, 1982).

The fifth strategy, supplication, is used to advertise weaknesses or shortcomings to seem in need of support or guidance (Jones \& Pittman, 1982). In this case the "supplicant's self-esteem is threatened" (p. 258). It is the "strategy of last resort" and is effect in "avoiding the negative reaches of others' power when one's own power resources are limited" (p. 260).

Jones and Pittman nevertheless argue that the five strategies are "interwoven in much of social behaviour" and the behaviour most always serves “other purposes as well as power augmentation" (1982, p. 260). The rubric, however encompassing, does not include all interpersonal behaviour (Jones \& Pittman, 1982). Further, it is not unlikely to "find certain experiences and certain personal resources would make one strategy more prominent than others" (p. 260). Also, these strategies can be "linked of fused" - one may precede the other or give way (Jones \& Pittman, 1982, p. 260). The strategies can "serve different functions for different audiences" (p. 250). Lastly, that the strategy may "trigger counterstrategies in the target person" (p. 260). For example, "self-promotion 
AUTHORS ONLINE: STRATEGIES FOR DIGITAL SELF-PROMOTION

gives rise to a competing self-promotion in the target" (Jones \& Pittman, 1982, p. 260).

The methodology chapter follows to explore the means this research took to explore these various theories. 


\subsection{Methodology}

\subsection{Case Study and Netnography}

This paper examined strategies for self-promotion of online authors using the social media platform, Wattpad, over a period of four months (January 2018 June 2018). For the purposes of this research I had chosen to use case studies and netnography methods. The case method examined the "many features" that are "detailed, varied and extensive" of a "small set of cases" over one period (Neuman, 2014, p. 42). It linked the data at the "micro level, or the actions of individuals, to the macro level, or large-scale structures and processes" and the surrounding situation (p.47). Further, it linked "concepts to actual lived experiences and widely accepted standards of evidence" (p.47

The case study method was used in my research for a variety of reasons. First, the social media platform, Wattpad, allowed me to examine posts on a specific date and time. I was able to capture the actual lived interactions of selfpresentation styles of four authors within the time frame of four months to compile four case studies. I focused on two practises: interactions that generate a follow-up response from commenters and, author posts (see Table 1 and Table 2 respectively following this section). To better understand the behaviour in each of the interactions, I classified them into codes using Jones and Pittman's strategies of self-presentation that are also found in the same tables (1982). These 
AUTHORS ONLINE: STRATEGIES FOR DIGITAL SELF-PROMOTION

strategies are: ingratiation, intimidation, self-promotion, exemplification, and supplication (Jones \& Pittman, 1982).

I used cross-case studies to compare strategies used by individual authors in the context of certain structures (e.g. social media platform, Wattpad and the social interaction between actors) to formulate self-presentation strategies used in best practices of self-promotion. These self-promotion strategies included: branding, interactions during special events, and author responses. In this way, I linked the data at the micro level of the author's interaction experiences to the macro level of structures and processes of social platforms that enabled these selfpromotion strategies to develop.

I used Netnography as a method because it is designed specifically for studying online communities. Kozinets (1998), originator of this method, defines netnography as a "qualitative method devised specifically to investigate the consumer behavior of cultures and communities present on the Internet” (p. 366). The portmanteau netnography combines the word "Internet" or "network" with ethnography (Kozinets, 1998). This method is used to understand online practices and behaviours that will identify which authors' self-promotion strategies increased their social profile in digital self-publishing. This paper helps us understand the environment of online author communities and publishing platforms. Consequently, it underscores those strategies of self-promotion in the 
AUTHORS ONLINE: STRATEGIES FOR DIGITAL SELF-PROMOTION

digital publishing era. The netnographic approach was vital for capturing Wattpad as a social environment, and consequently the dynamics and relationships within this environment.

\subsection{Sampling}

Using the netnographic method, I developed case studies of four selfpublished authors drawn from authors on the social media platform, Wattpad from January 2018 to June 2018 who had achieved "success" (see Appendix E). Essentially the "success" was derived using Wattpad's suggested "hot list" (see email Appendix F). The list is derived using "an algorithm generated list of Wattpad users" (Bold, 2016, p. 9). This "hot list" is available on their website under the tab, "hot list". The statistics used to determine "success" was based on the Wattpad users with: the most followers, the most reads or votes for their story/stories, or users who have recently acquired many new followers and awards on the platform (e.g. Watty award) (Bold, 2016). These authors had also achieved success in the form of traditional publishing or film deals and invitations to speak at conventions. A summary of authors (case studies) can be found in the Appendices A-D. Through this, I grouped information into three sections or selfpublishing strategies: branding, special events, and author response to determine the most effective uses or best practices of self-promotion in these areas. 
AUTHORS ONLINE: STRATEGIES FOR DIGITAL SELF-PROMOTION

The preliminary list of authors chosen for this study included two male and two female authors from a range of countries for a more objective profile: Canada (Case Study One: Brandon Wong); Malaysia (Case Study Two: Claudia Tan); U.S.A. (Case Study Three: A.V. Geiger); United Kingdom (Case Study Four: Shaun Allan). These authors created stories within the romance and horror genres for a young adult/adult audience. Authors who had not won a Watty award on Wattpad were not included because behaviour before and after an award announcement was the focus of this study.

\subsection{Data Collection}

Data was collected from January 2018-June 2018 using information derived from Wattpad. In more detail, data was drawn from time-stamped comments on author conversation boards, from the month before and the month following their most recent Watty award win. Wattpad voting periods generally last about a month and their timing also varied. Thus, the award announcement on each author's conversation page functioned as the marker of when to begin coding posts for the month preceding and following it. This was to track the frequency of author versus fan posts and the style of self-presentational outreach that preceded a successful win.

The data from conversation boards following an award was used to determine what comes next following an award win. For some, a win may mean 
AUTHORS ONLINE: STRATEGIES FOR DIGITAL SELF-PROMOTION

greater visibility. This study hoped to learn how much of a change in the activity of a page might be expected following an award announcement, and the ways that past winners had taken advantage of increased visibility.

The research question (strategies for on-line author self-promotion) also involved collecting data using Wattpad to determine which emerging authors provided examples of effective use of the platform. The metrics of popularity on Wattpad included: number of readers, number of followers and number of votes that would be collected as well as information regarding their presence on highvisibility pages such as the Wattys and the Featured Lists. These two metrics of popularity were cross-referenced to determine the authors that represented the top tier of emerging, self-published authors.

In determining branding self-promotional strategies used, I grouped and analyzed visual and textual elements to determine to what extent these authors develop a consistent identity across platforms. The importance of consistency in visual identity were linked with identification on branding (Cerand, 2011; Davies, 2017) and performance identity as well as cultivating relationships in virtual spaces (Boyd, 2017; Davidson, 2009; Flahive, 2017). To this end, I collected qualitative data about the author's chosen imagery including their avatar, background images, colours and slogans or phrases. 
AUTHORS ONLINE: STRATEGIES FOR DIGITAL SELF-PROMOTION

In determining the effect of an award on the activity on author conversation boards, I counted the number of author-generated and fan-generated posts on the conversation board for each author during the voting period: one month prior to receiving an award and one month following the announcement on their conversation board. Other discussions of Wattpad referred to the importance of direct reciprocity when community building (e.g. promoting a new author for them to repay the favour) (Bold, 2016; Davies, 2017).

This research noted the promotional activities authors engaged in both during voting periods and following award announcements. Further, I categorized each author-generated and fan-generated post for content. Coding schemes were applied to fan posts, to note if they were congratulatory, asked questions about author work, requested further information about the author, requested an interview or other (Table 1). A coding scheme was applied to author-generated posts to identify post types which are seen in Table 2. Jones and Pittman's taxonomy was included in the coding tables to classify and organize comments into self-presentation classes (1982).

In determining the level of consistency authors with a good following maintained in fan-author interactions on their conversation boards, I gathered information on the frequency of author replies of fan-generated comments from their conversation page. I also made notes regarding the content of conversations 
AUTHORS ONLINE: STRATEGIES FOR DIGITAL SELF-PROMOTION

that generated follow-up comments or increased activity from fans. In all, I collected four months of data from four independent authors on Wattpad.

\section{Table 1}

Coding Scheme for Interactions that Generate a Follow-up Response from Commenters

\begin{tabular}{|c|c|c|}
\hline Number & Meaning & $\begin{array}{l}\text { Relationship to Jones \& } \\
\text { Pittman Taxonomy }\end{array}$ \\
\hline 0 & Other & 0 \\
\hline 1 & Question about personal life & Ingratiation \\
\hline 2 & Requesting information about getting into writing & Supplication \\
\hline 3 & Congratulatory message & Ingratiation \\
\hline 4 & Compliment aside from direct congratulations & Ingratiation \\
\hline 5 & Request for interview & Supplication \\
\hline 6 & $\begin{array}{l}\text { Direct reciprocity (thanks - "shout out"- to an } \\
\text { individual fan) }\end{array}$ & Ingratiation \\
\hline 7 & $\begin{array}{l}\text { Technical question about Wattpad (for example: } \\
\text { How to access a work, where to find specific lists, } \\
\text { how to sign up for contests) }\end{array}$ & Supplication \\
\hline 8 & $\begin{array}{l}\text { Fan-initiated push to get more followers (\#200000 } \\
\text { and similar) }\end{array}$ & Exemplification \\
\hline 9 & $\begin{array}{l}\text { Questions about author's work on Wattpad (such as } \\
\text { what order to read it in or what they would suggest } \\
\text { they read first) }\end{array}$ & Supplication \\
\hline
\end{tabular}


Table 2

Coding Scheme for Author Posts

\begin{tabular}{|c|c|c|}
\hline Number & Meaning & $\begin{array}{l}\text { Relationship to Jones \& } \\
\text { Pittman Taxonomy }\end{array}$ \\
\hline $\mathbf{0}$ & Other & 0 \\
\hline 1 & Promoting a new book release & Self-promotion \\
\hline 2 & $\begin{array}{l}\text { Promoting a new chapter in an ongoing } \\
\text { digital publication }\end{array}$ & Self-promotion \\
\hline 3 & $\begin{array}{l}\text { Newsletter-style announcement about } \\
\text { changes to a previously published work }\end{array}$ & Ingratiation \\
\hline 4 & $\begin{array}{l}\text { Promoting another social channel with } \\
\text { content related to Wattpad creative work }\end{array}$ & Self-promotion \\
\hline 5 & Reminder for fans to vote & Supplication \\
\hline 6 & New content teaser (without details) & Self-promotion \\
\hline 7 & $\begin{array}{l}\text { Request for graphic designers to send in } \\
\text { art/designs for cover art }\end{array}$ & Supplication \\
\hline 8 & $\begin{array}{l}\text { Thanking fans for voting during the voting } \\
\text { period }\end{array}$ & Supplication \\
\hline 9 & Promotional event unrelated to voting & Supplication \\
\hline 10 & $\begin{array}{l}\text { Encouraging fans to vote for another author } \\
\text { (direct reciprocity) }\end{array}$ & Ingratiation \\
\hline 11 & Promoting older work & Self-promotion \\
\hline
\end{tabular}


12 Welcome message to new followers (May contain a refresher reading list of work that provides the reading order or similar catchup information)

13 Request from author for fans to add a work to a reading list/library (This is related to visibility on Wattpad)

14 Newly published book news

15 Promotions for published works (incentivising Wattpad followers to purchase a physical copy, drive sales)

16 Collaboration announcement (Invitation to collaborate or to read the product of a collaboration)

17 Link to author interview, spotlight or book review

18 Informative post (about community events such as Wattcon)
Ingratiation

Supplication

Ingratiation/Self-promotion

Supplication

Ingratiation/Ingratiation

Self-promotion

Exemplification 


\subsection{Data Analysis}

Drawing from the data in Tables 1 and 2, I constructed Table 3 to identify the predominate self-presentation strategy employed by each author of the case study and as a group. It differentiates between fan and author posts. The table also shows what the method was applied before and after an award.

\section{Table 3}

\section{Frequencies of Presentation Strategy Per Case Study and Overall}

\begin{tabular}{|c|c|c|c|c|c|}
\hline \multicolumn{6}{|c|}{ Case Study One } \\
\hline & Ingratiation & Supplication & Exemplification & $\begin{array}{c}\text { Self- } \\
\text { promotion }\end{array}$ & $\begin{array}{l}\text { Row } \\
\text { Total }\end{array}$ \\
\hline $\begin{array}{l}\text { Fan Posts (with } \\
\text { author follow- } \\
\text { up) }\end{array}$ & 15 & 1 & 0 & 1 & 17 \\
\hline $\begin{array}{l}\text { Author Posts } \\
\text { (Before) }\end{array}$ & 0 & 0 & 0 & 0 & 0 \\
\hline $\begin{array}{l}\text { Author Posts } \\
\text { (After) }\end{array}$ & 0 & 1 & 0 & 1 & 2 \\
\hline Column Total & 15 & 2 & 0 & 2 & 19 \\
\hline$\%$ SP/Total & $79 \%$ & $11 \%$ & $0 \%$ & $11 \%$ & \\
\hline \multicolumn{6}{|c|}{ Case Study Two } \\
\hline & Ingratiation & Supplication & Exemplification & $\begin{array}{c}\text { Self- } \\
\text { promotion }\end{array}$ & $\begin{array}{l}\text { Row } \\
\text { Total }\end{array}$ \\
\hline $\begin{array}{l}\text { Fan Posts (with } \\
\text { author follow- } \\
\text { up) }\end{array}$ & 0 & 0 & 0 & 0 & 0 \\
\hline $\begin{array}{l}\text { Author Posts } \\
\text { (Before) }\end{array}$ & 2 & 9 & 0 & 14 & 25 \\
\hline $\begin{array}{l}\text { Author Posts } \\
\text { (After) }\end{array}$ & 0 & 1 & 0 & 5 & 6 \\
\hline Column Total & 2 & 10 & 0 & 19 & 31 \\
\hline$\%$ SP/Total & $6 \%$ & $32 \%$ & $0 \%$ & $61 \%$ & \\
\hline
\end{tabular}


AUTHORS ONLINE: STRATEGIES FOR DIGITAL SELF-PROMOTION

\section{Case Study Three}

\begin{tabular}{lccccc}
\hline & Ingratiation & Supplication & Exemplification & $\begin{array}{c}\text { Self- } \\
\text { promotion }\end{array}$ & $\begin{array}{c}\text { Row } \\
\text { Total }\end{array}$ \\
\cline { 2 - 6 } $\begin{array}{l}\text { Fan Posts (with } \\
\text { author follow- }\end{array}$ & 3 & 1 & 1 & 0 & 5 \\
$\begin{array}{l}\text { up) } \\
\begin{array}{l}\text { Author Posts } \\
\text { (Before) }\end{array}\end{array}$ & 2 & 2 & 0 & 1 & 5 \\
$\begin{array}{l}\text { Author Posts } \\
\text { (After) }\end{array}$ & 2 & 5 & 0 & 5 & 12 \\
Column Total & 7 & 8 & 1 & 6 & 22 \\
$\%$ SP/Total & $32 \%$ & $36 \%$ & $5 \%$ & $27 \%$ & \\
\hline
\end{tabular}

\section{Case Study Four}

\begin{tabular}{lccccc}
\hline & Ingratiation & Supplication & Exemplification & $\begin{array}{c}\text { Self- } \\
\text { promotion }\end{array}$ & $\begin{array}{c}\text { Row } \\
\text { Total }\end{array}$ \\
\cline { 2 - 6 } $\begin{array}{l}\text { Fan Posts (with } \\
\text { author follow- }\end{array}$ & 2 & 2 & 0 & 0 & 4 \\
$\begin{array}{l}\text { up) } \\
\begin{array}{l}\text { Author Posts } \\
\text { (Before) }\end{array}\end{array}$ & 7 & 6 & 0 & 12 & 25 \\
$\begin{array}{l}\text { Author Posts } \\
\text { (After) }\end{array}$ & 9 & 5 & 2 & 9 & 25 \\
Column Total & 18 & 13 & 2 & 21 & 54 \\
$\%$ SP/Total & $33 \%$ & $24 \%$ & $4 \%$ & $39 \%$ & \\
\hline
\end{tabular}

\section{All Case Studies}

\begin{tabular}{lccccc}
\hline & Ingratiation & Supplication & Exemplification & $\begin{array}{c}\text { Self- } \\
\text { promotion }\end{array}$ & $\begin{array}{c}\text { Row } \\
\text { Total }\end{array}$ \\
\cline { 2 - 6 } $\begin{array}{l}\text { Fan Posts (with } \\
\text { author follow- }\end{array}$ & 20 & 4 & 1 & 1 & 26 \\
$\begin{array}{l}\text { up) } \\
\begin{array}{l}\text { Author Posts } \\
\text { (Before) }\end{array}\end{array}$ & 11 & 17 & 0 & 27 & 55 \\
$\begin{array}{l}\text { Author Posts } \\
\text { (After) }\end{array}$ & 11 & 12 & 2 & 20 & 45 \\
Column Total & 42 & 33 & 3 & 48 & 126 \\
$\%$ SP/Total & $33 \%$ & $26 \%$ & $2 \%$ & $38 \%$ & \\
\hline
\end{tabular}

Note: SP=Self-Presentation Strategy Class; Before=Before an award; After=After an award 
AUTHORS ONLINE: STRATEGIES FOR DIGITAL SELF-PROMOTION

To assess the author's two-way communication and engagement strategies I developed another set of criteria. These included: author posts frequency (and subject matter), fan posts frequency, author reply frequency to fan generated posts, and the number and subject matter of author replies to fans that generated further comments from fans.

These criteria were used to understand the integration of various tactics based on Jones and Pittman's taxonomy into communication strategies for the writers' award-winning publications. The criteria were used to identify the cultivation of a cohesive identity through the integration of the authors' other social media profiles. This formed the textual identity and reflected the audience, through adoption of "fan" language "quirks" such as the use of slang and punctuation (Boyd, 2008) and the level and frequency of engagement including posts, replies to fans on their page and installments of their written works. The subject matter of the posts was analyzed using Jones and Pittman (1982) taxonomy of attributes and self-presentation rubric to illustrate the nature of their two-way interactions. It helped to identify the self-presentation phenomena. 
AUTHORS ONLINE: STRATEGIES FOR DIGITAL SELF-PROMOTION

Drawing from the data extrapolated from the case studies cited in the literature review and the branding theories of Gyrd-Jones, Merrilees, and Miller (2013) I developed a list of criteria to assess their branding. As branding can be a self-promotion method, I used identity to analyze the strategies within. These included: consistent use of their name and "handles" (public usernames used to identify people) across their social media channels; the connectivity of their platforms, and; visual identity.

\subsection{Findings}

The following research findings are divided into sub-headings to illustrate: patterns of self-presentation strategies using Jones and Pittman rubric, strategies of self-branding using the theory of identity, impact of special events on engagement, and the impact of author replies to fan behaviour.

\subsection{Patterns of Self-Presentation Strategies}

The authors in this study used self-promotion (38\%) and ingratiation (33\%) self-presentation strategies most often. They also employed a moderate use of supplication (26\%), while exemplification was rarely used (2\%), and intimidation not found at all during the sample collection period.

Half of the authors used self-promotion strategy frequently through their posts (Case Study 1 and 2). While one author used the ingratiating strategy most, 
AUTHORS ONLINE: STRATEGIES FOR DIGITAL SELF-PROMOTION

it was almost equal to the use of the self-presentation class, illustrating the popularity of this method. One other employed much use of the ingratiating tactic $(79 \%)$.

Across all four authors in the case studies, self-promotion was used most to emphasize the author's achievements thereby drawing attention to their expertise and competence in their writing field. For example, self-promotion was used in many cases: when authors posted a direct link to interviews, spotlighted or highlighted a book review, book release, new chapter in a digital publication, and new content teasers. The self-promotion strategy was seen most often among the author posts (Jones \& Pittman, 1982). The ingratiating strategy was most often used by fan posts as congratulatory forms and compliments.

\subsection{Strategies for Self-Branding on Wattpad}

The branding strategies implemented by the authors in this study included: consistent naming conventions across channels; consistent visual identity including author avatar and background images when included which conveyed a consistent identity as indicated through the biographical text, and; associated slogans and frequency of fan interaction.

The authors involved in this study generally used consistent names and handles, "primary global identifiers for digital objects" (Kahn \& Wilensky, 1995, p. 1), across their social media channels and included direct links to at least one 
AUTHORS ONLINE: STRATEGIES FOR DIGITAL SELF-PROMOTION

other social channel. Further, these other social channels were advertised in author-generated posts during and following the voting period, indicating interrelated content that is relevant to their works posted on Wattpad.

The social channels most often used by these authors included Facebook, with Twitter and Instagram directly linked in three out of four cases. While the content of the linked accounts was not part of this study, it is worthwhile to note that the visual identity used in related channels linked with Wattpad accounts. Most often, the visuals included images of digital book covers of Wattpad offerings and explicit reference to recent work, collaborations and awards in the biography text.

\subsection{Impact of Special Events on Engagement}

Social engagement in terms of fan-generated posts typically increased following a special event (e.g. award). For example, Case Study One saw a 63\% increase in fan-generated posts, Case Study Four saw a 50\% increase, while Case Study Three saw an increase of $71 \%$. On average there was an increase of $61 \%$ of fan-generated posts following an award.

Conversely, there can be times when there is not an increase. For example, Case Study Two saw a decrease in fan-generated posts following an award. However, this was an anomaly and can be attributed to two factors. For one, the author did not provide personal information to the extent other authors 
AUTHORS ONLINE: STRATEGIES FOR DIGITAL SELF-PROMOTION

did. Another reason could be due to lower author reply rate to fan-generated posts.

There was a positive correlation between fan-generated activity and author response frequency. Generally, increased fan-generated posts were found in cases with a higher frequency of author-responses to fan-generated posts. This was found in Case Study One, Three and Four.

Author-generated posts generally also increased following an award, and on average, author posts increased by $70 \%$ following the award announcement in the authors studied. In Case Study One, author-generated posts increased to two from none and was the outlier in this study as Wong did not engage in selfpromotional activities during the voting period. In Case Study Two, Tan generated six posts, down from 27 , following the voting period. This is interesting as it is the only case where author activity decreased following a win. This may be due to the nature of her activity prior to her win: many posts created during the voting period were directly related to funneling her followers to the voting page and advertising her new work, which launched on the same date as the award announcement. Tan also did not collaborate, projects or enter any other competitions following the initial one. This suggests that her focus had been solely on campaigning for her Watty rather than using the notoriety from the Watty as a stepping stone to something else. 
AUTHORS ONLINE: STRATEGIES FOR DIGITAL SELF-PROMOTION

In Case Study Three, the author posts increased by 36\%. Geiger's posts promoted her newly-commercially published work, her involvement in a new writing contest and the promotion of other Wattpad authors. In this case Geiger increased her post frequency following an award to promote sales. However, she emphasized that contests were instrumental in her self-promotion and encourages her fans to also follow suit. Her explicit link between her growth through contests is an ingratiating technique (Pittman, 1982). Involvement in contests allowed Geiger to be vetted by established authors and built her author brand. Her continued participation furthers her notoriety.

In Case Study Four, Allen's post frequency rose by $67 \%$ following his award. His posts consisted of promotions for his existing commercially-published and Wattpad-based work (including new collaborations). He also recommended other Wattpad-based authors to his following, as Pittman (1982) notes as ingratiating behaviour. These recommendations rewarded his followers who gained helpful suggestions, and collaborators who received free positive advertising by word-of-mouth. Allen's collaborations further added to his author brand through affiliation with trusted authors (Foucault, 1977).

Author activity prior to award announcements varied. In Case Studies Two, Three and Four, the authors posted on average once a day during the voting period, with posts that directly linked to the voting page and encouraged fans to 
vote for their work. In Case Study One, author-generated posts were very low, (none prior to the award announcement) but their outreach included a high response rate to fan posts.

In summary, author activity following award announcements varied in terms of frequency, but in general authors posted more often following their award wins. The subject matter following a win included ingratiating posts such as thanking fans for support, invitations to writing contests and information for new fans (e.g. a list of works with their intended order). They also included content meant to impact perceived legitimacy, such as collaborative projects and changes to works already available. Finally, they promoted new content, inviting fans to read and comment or visit other social channels which contained relevant content for their readers. All of these are examples of ingratiation methods in selfpromotion.

\subsection{Impact of Author Reply Frequency on Fan Behaviour}

The authors involved in this study varied in the number of times they directly responded to fan-generated comments on their conversation boards. On average, authors in this study responded to $70 \%$ of fan-generated posts prior their awards and 58\% following their award.

Case Study One responded to $71 \%$ of fan posts prior to his award, which rose to $91 \%$ following his award announcement. Case Study Three responded to 
AUTHORS ONLINE: STRATEGIES FOR DIGITAL SELF-PROMOTION

$93 \%$ of fan posts prior to the award announcement and dropped to $57 \%$ following the award. Case Study Four responded at a rate of $90 \%$ prior to their award and $80 \%$ following. The lowest response rate was Case Study Two with $27 \%$ prior to the win and only seven percent following it, proving that an infrequent response rate does not preclude success, but it may undermine the potential for growth associated with times of increased visibility or potential traffic. 


\subsection{Discussion}

\subsection{Self-Presentation Strategies}

Drawing from Jones and Pittman's (1982) taxonomy of attributes the case studies exhibited the following strategies of self-presentation of: ingratiation, selfpromotion, exemplification, and supplication. The attributions "are in the ultimate interests of power maintenance" (Jones \& Pittman, 1982, p. 258). Therefore, most attributions were found save for intimidation where this powerreducing action may be maladaptive. Tables 1 and 2 demonstrated how those attributions were applied and Table 3 showed the frequency of their use.

While most classes under Jones and Pittman were found in author and fan post types, intimidation was absent. This is because of the type of collaborative environment that Wattpad represents. Collaborative environments (Kinberg, 2014) are described as maintaining a fluid heterarchy with ad hoc meritocracy, they depend on a lack of a solid hierarchy to work properly and those that do not work well within the group will be filtered out. Generally, intimidation strategies are performed when the person is of a high-power relative to their targets (Jones \& Pittman, 2018, p. 259) and this is not the case. Intimidation would emphasize threat and the manipulation of fear rather than positive emotions (p. 259) which is not to the advantage of self-publishing. It is little wonder this strategy was lacking in the findings. 
AUTHORS ONLINE: STRATEGIES FOR DIGITAL SELF-PROMOTION

The predominant self-presentation strategy used was self-promotion (38\%). This strategy is used to arouse respect. It can be applied to performance claims. The attribute sought is competence and respect. Most authors (Case Study Three and Four) applied this prior to an award. This method is appealing to the author when encouraging followers. However, as noted by Jones and Pittman, overuse can illicit negative attributions such as conceit, fraudulent or defensive (1982). This can be seen in the overuse of self-promotion in Case Study Two. In this study, the author applied the strategy $61 \%$ of the time, most prior to an award. This would be further offset as she does little ingratiating (use is only 6\%) to be likeable. In all, it appears this strategy may not build the social presence or the attribute she is seeking.

Following self-promotion, ingratiation was used the next highest strategy $(33 \%)$. Ingratiation invokes affection to seem likeable and is generally use in "self-characterization, opinion conformity and other enhancement favors" (Jones \& Pittman, 1982, p. 249). It can be seen within conversational activities to achieve likeability. This may include praising, agreeing with, or flattering a target audience. It can be used by authors attempting to sell themselves and a product where they are in a dependent or low-power position. This was used prior and after an award, for example, as a show of appreciation. It was also used in Case Study Four where the author dedicated a chapter to a fan. As Jones and Pittman explain, this strategy is "boosted when we find ourselves in a dependent or low- 
AUTHORS ONLINE: STRATEGIES FOR DIGITAL SELF-PROMOTION

power position" (p. 258). There are times when the ingratiator want to believe in their sincerity, and conversely, the target person wants to believe in the sincerity of the compliments. In Case Study Two, there is no dialogue to fans following an award, thus projecting the attribute of insincerity on the part of the author. However, establishing credibility is a major task for the author. In this way, the authors must be careful not to seem insincere

It is worth noting that ingratiation was used extensively in Case Study One as a follow-up to fans rather than before an award. The lack of self-promotion $(11 \%)$ in this case, gave the impression of humility or supplication through its absence. For this reason, the award may have been granted for this humble persona.

The strategy of supplication was the third most used strategy. Supplication intends to rouse nurturance or obligation. The attribution sought from the fans was that of helpless or one of unfortunate circumstances. It was used extensively before an award announcement, during the voting period. This is because the supplication posts indicated the need for fan votes. There were enough votes to win a Watty, therefore, it can be assumed that this was an effective strategy.

Lastly, the strategy of exemplification was used least. Exemplification involves "self-denial, helping, militancy for a cause" to arouse "guilt (shame, 
emulation)" (p. 249). The attribution sought is moral worthiness and integrity. It is the conditions of arousing guilt and shame that the authors may not favour this strategy. Authors could pair with others for a moral cause and thus using this strategy. However, this was not seen.

In closing, the self-presentation strategy of self-promotion and ingratiation were both used by the authors. There was little use of exemplification and none observed for intimidation. More can be discussed through their branding.

Similarly, situational theory (Grunig, 2010) or the persona enacted by each author tends to reflect a specific identity that was to be cultivated, either because the author truly saw themselves this way or because the author wants to be viewed in a certain light by the fans. Both these attributions of self-presentation and examples of situational theory can be found in the following strategies of best practices.

\subsection{Strategies for Self-Branding on Wattpad}

Consistency was key to conveying an author identity that allowed fans to find each author across social channels. Direct links to alternate social channels made it easier for fans to find authors and follow them. The use of consistent 
AUTHORS ONLINE: STRATEGIES FOR DIGITAL SELF-PROMOTION

imagery, with references to Wattpad contributions both in text (e.g. Watty winner) and in the colour (colours used echo those used in Wattpad profile) and images (e.g. of digital book covers, or of the book itself) chosen maintained a consistent, recognizable visual identity.

To draw from situational theory, the persona enacted by each author tends to reflect a specific identity that was to be cultivated, either because the author truly saw themselves this way or because the author wants to be viewed in a certain light by the fans (Grunig, 2010). For example, Wong (Case Study One) portrayed himself as a friendly, outgoing, positive person and this was reflected in the slogans he used in related accounts, such as "Later Haters". He had further portrayed himself as Canadian - as his nationality appeared at the top of his biography (rather than the bottom where it appears for all other authors in this study).

This may be purposeful as Canadians have an international reputation as polite hockey enthusiasts, and his most popular work focused on hockey. Wong's friendly, polite persona also informed his conversations with his fans which will be discussed in greater detail below. There was a tendency for an author to present a consistent persona in one's visual identity, author posts and fan interactions. Each of these, while discussed separately in the context of this paper, should be recognized as intertwined. In semiotics, the relationship between words 
AUTHORS ONLINE: STRATEGIES FOR DIGITAL SELF-PROMOTION

and images is also seen as inseparable, and this remained true for the various aspects of each author's persona as they are enacted in the online presence.

The self-presentation of each author studied was related. Case Studies One and Two each presented themselves as young, trendy, and academically inclined authors as they included information about their studies and incorporated avatars that show them in trendy clothing (a casual, fitted white dress shirt on Wong in Case Study One and a drawn avatar of Tan in Case Study Two showing the author wearing a cropped tank top and torn denim shorts). The choice to portray a casual, trendy and youthful appearance can elicit a sense of similarity in fans.

Slogans were only used by one author (Case Study One). They were included graphics resembling juvenile art in the background image of his directly linked Facebook account. This case was interesting as the author's style was very friendly and open in his direct engagement with fans. One example of a fan interaction indicative of his style is the following:

Hi... I just wanted to say that u seem like a very nice person, like genuinely. I am a person who sees the negative in everything but reading ur stories and the conversations.... u look so nice I want to die, like really. In this world there's hardly a person who talks to strangers nicely but hey guess what, I found one! And that's u! Hope to read more of ur works. Always staying a fan! :-) (debaclelove, 2018)

Hi! Thank you for the message! It's always nice to read these from readers. I think it's too easy to get sucked into seeing the negatives, so I'm doing my best to stay positive. Sometimes it doesn't always work, but for the most part, it makes life a little more fun. Thanks for reading my work, by the way! Stay tuned for what's coming! (BrandonWong048, 2018) 
AUTHORS ONLINE: STRATEGIES FOR DIGITAL SELF-PROMOTION

While he does not mimic their shorthand, Wong's punctuation and enthusiasm echoes those of his fans. It follows that interactions should mimic the sentiment as understood through Jones and Pittman's taxonomy.

Interactions are generated in some cases where fans seem compelled to reach out and thank him because he was consistently kind. To use Jones and Pittman's taxonomy, this fan behaviour could be ingratiation, or generated by their desire to be liked (by the author or potentially Wong's other fans), and in this case that desire was fulfilled by Wong's response, in which he portrays himself as others-focused, rewarding the fan for seeking him out.

In all cases, the directly-linked social channels contained references to their status on Wattpad and two (50\%) included imagery that directly related to their work on Wattpad, either in the form of digital book covers, sections of their covers and quotes from their work as well as imagery closely linked with their chosen genre. Interestingly, only one (20\%) included imagery related to the work in their Wattpad avatar (Case Study 4).

The chosen avatars of each author included close-cropped photographs of the authors in all but one case (Figure 1). These images reflected the casual nature of the platform in the casual clothing visible (when it was included) in the image. Some authors chose to portray themselves as trendy, such as Case Study Two. In this study, Tan both trendy (resembling the popular adult-cartoon Archer) and 
modern (the avatar was sporting a tank top and torn denim shorts. In her avatar, her gaze was facing away from the viewer and carried an aloof, edgier appeal than Wong's avatar: a photograph in which he sits at a table at a convention wearing a white button-up shirt and a large smile. When viewed together, you would expect Tan's interactions with her fans to reflect the aloof impression given by her avatar, and that expectation would be correct.

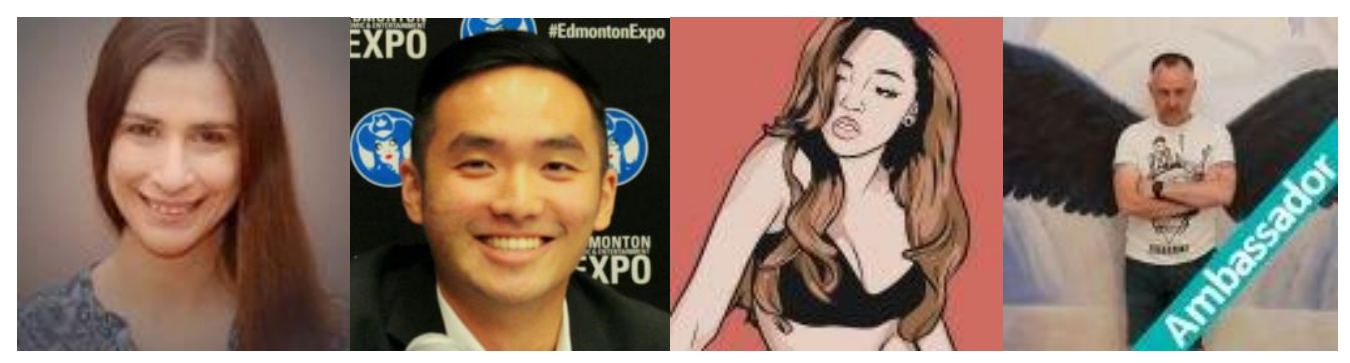

Figure 1: Author Avatars (left to right): A.V. Geiger, Brandon Wong, Claudia Tan and Shaun Allen

Case Study Three presented a very neutral, close-cropped avatar of the author. While her clothing wasn't visible due to the cropping of her chosen avatar, her natural, fresh-faced appearance and loose, long straight hair indicate youth, which can appeal to her young audience.

In Case Study Four, the author was visibly older than the other authors studied and rather than trying to present himself as youthful, he presented himself as somewhat quirky as his choice of avatar was himself standing against a mural 
in casual clothing. This was a tongue-in-cheek reference to some of the works offered on the site and gives the impression that Allen does not take himself too seriously. This may be done to elicit the reaction from fans that despite his professional success, this author is approachable

\subsection{Impact of Special Events on Engagement}

To take advantage of the increased visibility and corresponding boost in audience that come with an award win and subsequent inclusion on highervisibility lists the authors involved in this study generally increased the frequency of their posts. Each author involved in this study posted about new work, new collaborations and newly-published work following their respective wins, encouraging fans to add their new work to their reading lists, which in turn affected visibility due to the algorithms presented on the site.

\subsection{Impact of Author Reply Frequency on Fan Behaviour}

The authors studied did not all reply often to fan posts, and some had very little fan-generated activity on their wall. In the cases where authors generated posts daily, fan-generated posts tended to drop (Case Study Two). It may be that what really mattered was not the number of posts, but the content.

The performance of identity as demonstrated through associated visuals was briefly described above. In Case Study Two, Tan presented an aloof 
AUTHORS ONLINE: STRATEGIES FOR DIGITAL SELF-PROMOTION

(unaffected, unemotional), cool, unfeeling persona, her fan interactions could also be called aloof. Despite the lack of dissonance, this did not lead to a positive correlation in terms of fan-post activity. When comparing Case Studies One (Wong) and Two (Tan), Tan's fan interactions were less frequent than Wong's and dropped following her Watty win: 26 of 94 fan comments had replies from Tan. However, that dropped to seven out of 93 following her win. In contrast, Wong answered 15 of the 21 fan comments received during the voting period, which rose to 30 out of 33 following his Watty win. From one perspective, Tan had more comments on her board, but the award did not generate an increase in fan activity when compared with the voting period. In fact, it had decreased, while Wong's rose by almost $50 \%$. This indicated a positive correlation between fan activity and the frequency of author response rate.

Higher fan activity was not necessarily positive. If fans were posting questions regarding the correct reading order or available works for example, but receiving no response from the author, that fan activity may not necessarily be positive. This was because it could potentially lead to negative feelings not only from that fan but from other fans who saw that there was no response and perceived the author as aloof. Proactive posts from authors that helped new fans navigate their work and pointed them in the direction of contests and opportunities to develop as writers, a practice that Wong, Geiger and Allen 
AUTHORS ONLINE: STRATEGIES FOR DIGITAL SELF-PROMOTION

engage in, may be more effective in generating goodwill among followers as each of these authors saw an increase in fan-generated activity.

Interestingly, the types of conversations that most often resulted in followup comments from fans were when authors replied to congratulatory fan messages. To borrow from Jones and Pittman's taxonomy, these are ingratiating fan comments which seek to curry favor from the author. Answering with supplicating author responses, which indicated weakness or shortcomings (e.g. their reliance on fan support for continued success and motivation) typically generated the highest number of follow-up fan responses. An example was fan comments that praised the accomplishments of an author when met with an author response that thanked the fan and advertised a weakness such as the difficulty of getting started in a writing career.

In Case Study Two there were many exemplification posts, meaning these sought to demonstrate devotion. For example, noting the high number of votes entered in during a voting period. In Case Study Four one of the fans who went above and beyond for the author was rewarded with a supplication post from the author expressing gratitude to the fan for the efforts and further dedicated a section of the work to this fan. The behaviour of fans following author posts indicated acknowledging the need for support encouraged its continuance. Every 
AUTHORS ONLINE: STRATEGIES FOR DIGITAL SELF-PROMOTION

author had their own voice but displayed appreciation should be responded to in kind for authors seeking to grow their audience. 


\subsection{Conclusion}

This research project sought strategies of self-promotion for online authors. It did this through examining four case studies of online authors that use Wattpad as a social platform. The promotional strategies investigated were organized under three headings: branding, special events, and author responses to fans.

Drawing on the strategies, the impact and frequency of each was measured and assessed to understand the practices exemplified across each case study during a period of potential growth through greater visibility (a special event) branding and author reply frequency. This contributed to the author's online visibility and may be invaluable for self-promotional authors. It was determined that these practices were effective in raising the author's profile.

Elements such as branding, and author reply frequency during a special event as well as type (e.g. self-promotion, ingratiation, supplication) can increase an author's social profile and hence promote an author in the sea of authors. Though some tactics may not provide immediate benefits, these tactics may have long-lasting social impacts. These included increased engagement in the community of followers on social platforms. These followers can become advocates through direct means such as voting or providing recommendations 
AUTHORS ONLINE: STRATEGIES FOR DIGITAL SELF-PROMOTION

through inclusion on reading lists. This exposure is invaluable for selfpromotional authors.

The online behaviour of the authors was also examined through though a framework of taxonomy of attributes within a rubric of self-presentation strategies found through the literature review (Jones \& Pittman, 1982). These included: ingratiation, self-promotion, exemplification, and supplication. This showed that self-presentation strategies or impression management tactics were useful and employed in cultivating brand identity. The self-presentation strategies used by the authors in this study included: ingratiation, self-promotion, exemplification, and supplication (Jones \& Pittman, 1982). There was little evidence of intimidation practices. 


\subsection{Limitations}

In terms of performance of identity, it would be more thorough to also analyze the construction of an author's biography and note the types of information the successful authors included to gain a better sense of what works. Some authors choose to include only information directly related to their published works, while others include information about their personal life, like marital status, age and number of children.

While this study focused exclusively on author behaviour for one month before and following an award announcement (coinciding with the month-long voting period Wattpad favors), it would also be interesting to note author behaviour of other special events related to increased visibility, for example, Wattpad "Block Parties" and other writing contests hosted on the platform.

The data gathered for this study was entirely derived from conversation board activity. To develop a more holistic understanding of the extent of fanauthor collaboration as it exists on Wattpad, it would be helpful to also delve into the comment boards housed within individual chapters of works where more constructive criticism and less general comments reside.

Collaborations are popular on Wattpad, and some of these feature very well-known authors working with slightly less well-known authors. The mutual benefit of collaboration and co-creation on Wattpad and the community outreach 
that accompanies these creative efforts would be a reasonable avenue for further study.

The authors included in this study have enjoyed professional successes following their creation of their Wattpad profiles, but it would be interesting to study when they received representation relative to their activity on Wattpad and across their other channels to develop a richer understanding of their activity, following size, and the specific style of outreach they engaged in at that time. Unfortunately, some Wattpad user conversation boards have unpredictable end points that limit the extent to which research can be done. For this reason, some authors that would otherwise be included in this study were omitted. 


\section{Appendix A: Case Study One: Brandon Wong}

\section{Branding}

Name and Handles: Consistent name and handle across most channels.

\begin{tabular}{|c|c|c|c|c|}
\hline Social Platforms & $\begin{array}{c}\text { Name/Handle on } \\
\text { Each Platform }\end{array}$ & Avatar Notes & $\begin{array}{l}\text { Wallpaper Image } \\
\text { Notes }\end{array}$ & Slogan Notes \\
\hline Wattpad & \begin{tabular}{|l|} 
Brandon Wong \\
$@$ Brandonwong048
\end{tabular} & $\begin{array}{l}\text { Full-colour image } \\
\text { of Brandon Wong, } \\
\text { standing against a } \\
\text { red-brick wall } \\
\text { backdrop, dressed } \\
\text { in a casual, plain, } \\
\text { crisp, clean white } \\
\text { dress shirt. }\end{array}$ & $\begin{array}{l}\text { The wallpaper is of } \\
\text { a mountain covered } \\
\text { in evergreen trees }\end{array}$ & $\begin{array}{l}\text { None included, } \\
\text { however, his "about } \\
\text { me" section includes } \\
\text { his Canadian } \\
\text { citizenship and a } \\
\text { brief explanation } \\
\text { about his connection } \\
\text { with hockey as it ties } \\
\text { into his work. }\end{array}$ \\
\hline $\begin{array}{l}\text { Facebook (Direct } \\
\text { Link) }\end{array}$ & Brandon Wong & $\begin{array}{l}\text { Full-colour image } \\
\text { of himself (sitting } \\
\text { at a table in front } \\
\text { of a mic with } \\
\text { "Edmonton Expo" } \\
\text { printed on the mic } \\
\text { and backdrop, } \\
\text { likely from a } \\
\text { speaking } \\
\text { appearance. } \\
\end{array}$ & $\begin{array}{l}\text { Blue field with } \\
\text { cartoon-style } \\
\text { graphics of a hand } \\
\text { making the peace } \\
\text { sign and slogans } \\
\end{array}$ & $\begin{array}{l}\text { Slogans included in } \\
\text { the background } \\
\text { image include "later } \\
\text { haters" and "writing } \\
\text { contest" as of June } 4, \\
2018\end{array}$ \\
\hline $\begin{array}{l}\text { Twitter (Direct } \\
\text { Link) }\end{array}$ & @brandonwong048 & & $\begin{array}{l}\text { The wallpaper is } \\
\text { also of a mountain, } \\
\text { covered in snow, } \\
\text { with evergreen trees }\end{array}$ & None included \\
\hline $\begin{array}{l}\text { Instagram (Direct } \\
\text { Link) }\end{array}$ & @brandonwong048 & & & N/a \\
\hline $\begin{array}{l}\text { Goodreads } \\
\text { (Direct Link) }\end{array}$ & Brandon Wong & \begin{tabular}{|l|} 
Full-colour image \\
of Brandon Wong, \\
standing against an \\
indoor, \\
professional \\
building backdrop,
\end{tabular} & & \\
\hline
\end{tabular}




\begin{tabular}{|l|l|l|l|}
\hline & $\begin{array}{l}\text { dressed in a plain, } \\
\text { crisp, blue dress- } \\
\text { shirt. }\end{array}$ & \\
\hline
\end{tabular}

*Direct Link indicates profiles that are directly linked to on Wattpad profile

\section{Visual Identity}

Avatar: Image was a full-colour photographic image of himself in all cases.

\section{Accompanying Images / Background Image:}

Wattpad (landscape with trees), Facebook (background with slogans and handdrawn icons)

Slogans: "Later Hater" and "Writing Contest" - Specifically referenced back to his identity on Wattpad as a contributing writer.

Findability: His other social platforms were linked to his Wattpad account and included Snapchat, Twitter and Facebook and his author website, allowed followers to connect with him using any platform they choose, rather than focusing on only one.

\section{Performance of Identity: Gender, Genre, Race (Visible Minorities), Thematic}

\section{Ties to Novels, Interests}

Wong maintained a consistent visual identity across his channels, with similar imagery or snow-capped mountains used across his channels. Wong was a male author writing in a genre dominated by women: romance, and specifically 
AUTHORS ONLINE: STRATEGIES FOR DIGITAL SELF-PROMOTION

Canadian romance featuring hockey as the backdrop to his story. He used his identity as a Canadian citizen in his biography, included it as the third bullet in his “about me" section. Wong's voice was consistent across platforms, with an engaging, interested style. His status as a visible minority in Wattpad seemed to resonate with fans, and this was reflected in the comments on his conversation board.

Play by the Rules also known as PTBR won 2016 Wattys \#1 in Teen Fiction November 4, 2016

\begin{tabular}{|l|l|l|}
\hline $\begin{array}{l}\text { Date of Award } \\
\text { announcement }\end{array}$ & $\begin{array}{l}\text { Number of comments in the } \\
\text { month before award } \\
\text { announcement }\end{array}$ & $\begin{array}{l}\text { Number of comments in the } \\
\text { month following award } \\
\text { announcement }\end{array}$ \\
\hline November 4, 2016 & 21 & 33 \\
\hline
\end{tabular}

The discussion on Wong's page grew to 33 from 21 comments in the month preceding his Watty award announcement on November 4, 2016. His comment board contained 23 congratulatory comments including the words "congratulations," "congrats" or mentioning the term "Watty" in an oblique way, for example: "Truly deserving a Watty" (Iridescent, November 26, 2016). Each of these comments received a reply. 
There was the limitation that the statistics of each of his posted works cannot be viewed, so it can not be seen if the comments on his board came from fans who read his work but the activity on the wall alone was indicative of fan engagement.

\begin{tabular}{|c|c|c|c|c|c|c|c|c|c|}
\hline 1 & 2 & 3 & 4 & 5 & 6 & 7 & 8 & 9 & 10 \\
\hline $\begin{array}{l}\text { Total } \\
\text { number } \\
\text { of author } \\
\text { posts in } \\
\text { the month } \\
\text { before an } \\
\text { award } \\
\text { announce } \\
\text { ment }\end{array}$ & $\begin{array}{l}\text { Total } \\
\text { Number } \\
\text { of fan } \\
\text { comment } \\
\mathbf{s} \text { in the } \\
\text { month } \\
\text { before } \\
\text { award } \\
\text { announce } \\
\text { ment }\end{array}$ & 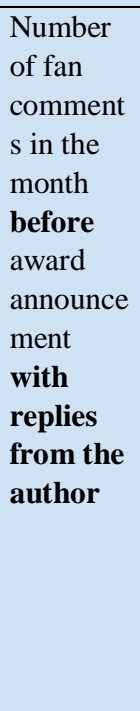 & 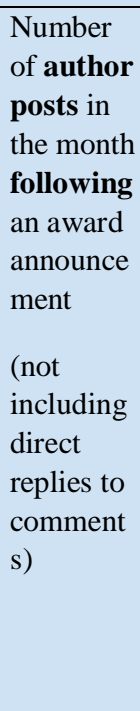 & $\begin{array}{l}\text { Total } \\
\text { number } \\
\text { of fan } \\
\text { comment } \\
\mathrm{s} \text { in the } \\
\text { month } \\
\text { following } \\
\text { award } \\
\text { announce } \\
\text { ment }\end{array}$ & 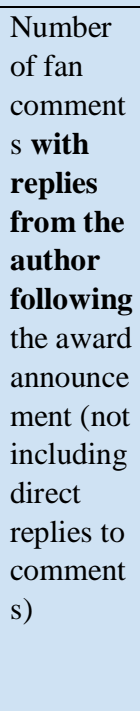 & 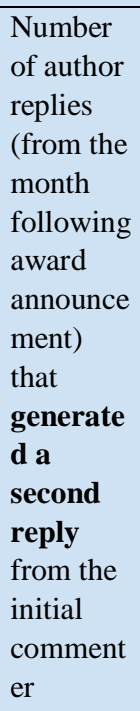 & $\begin{array}{l}\begin{array}{l}\text { Nature } \\
\text { of } \\
\text { conversa } \\
\text { tion that }\end{array} \\
\text { generated } \\
\text { follow-up } \\
\text { reply }\end{array}$ & 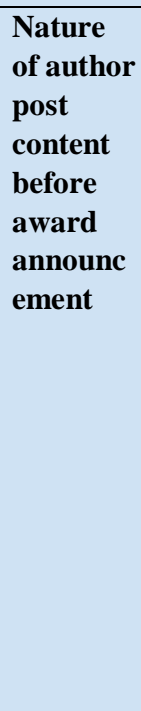 & $\begin{array}{l}\begin{array}{l}\text { Nature } \\
\text { of author } \\
\text { post }\end{array} \\
\text { content } \\
\text { following } \\
\text { award } \\
\text { announc } \\
\text { ement }\end{array}$ \\
\hline 0 & 21 & 15 & 2 & 33 & 30 & 16 & $\begin{array}{l}3, \\
3, \\
3, \\
3, \\
3, \\
3, \\
3, \\
3, \\
3, \\
3, \\
3, \\
3, \\
3, \\
3 / 1, \\
4, \\
5,\end{array}$ & N/a & $\begin{array}{l}1, \\
8,\end{array}$ \\
\hline
\end{tabular}




\section{Impact of Special Events}

During the voting period, Wong did not create any author posts. He never requested fans vote during this period, but he did engage with fans by responding to 15 of the 21 fan comments on his conversation page. Following his award announcement, Wong created two posts, plugging a newly-released publication and thanking fans for voting. He also continued to respond to fans who posted on his conversation board, responding to 30 of the 33 fan posts generated during this period. Of the posts he responded to, 16 generated further fan interactions.

\section{Interpersonal Factors}

Wong did not reach out to fans during the voting period with authorinitiated posts but instead engaged in dialogue by replying to $71 \%$ of fangenerated comments and $91 \%$ following an award announcement. In his two posts following the announcement, he used one to announce a new work on Wattpad and the other to thank fans for their recognition. His replies to fan comments are typically enthusiastic thanks for their support in all its forms, whether a vote, library add, congratulatory message or an emoji left as a comment on his page. For example, in his conversation with @_Mouse_Girl_complimenting his Wattywinning work, Playing by The Rules, he replied "Thank you so much! That is high praise considering the amount of talent that is present here on Wattpad! I'm really happy to hear that!" (November 18,2016$)$. He actively encouraged fans to 
AUTHORS ONLINE: STRATEGIES FOR DIGITAL SELF-PROMOTION

comment on his work on his wall and rewarded their continued activity on his conversation board through consistent interaction.

The comments on Wong's conversation board that were congratulatory led to the highest number of follow-up responses from fans. Wong consistently answered these fans with effusive thanks, matching the level of excitement fans used in their initial outreach. 


\section{Appendix B: Case Study Two: Claudia Tan}

\section{Branding}

Joined Wattpad: November 4th, 2014

Name and Handles: Consistent vs. variable

Tan did not use consistent naming across channels but did directly link her

Facebook profile from her Wattpad profile.

\begin{tabular}{|c|c|c|c|c|}
\hline Social Platforms & $\begin{array}{c}\text { Name/Handle } \\
\text { on Each } \\
\text { Platform }\end{array}$ & Avatar Notes & $\begin{array}{c}\text { Wallpaper } \\
\text { Image Notes }\end{array}$ & Slogan Notes \\
\hline Wattpad & $\begin{array}{l}\text { Claudia Tan } \\
@ \text { Claudiaoverhe } \\
\text { re }\end{array}$ & $\begin{array}{l}\text { Full colour } \\
\text { cartoon that } \\
\text { resembles the } \\
\text { author. }\end{array}$ & & $\begin{array}{l}\text { Tan does not } \\
\text { include slogans } \\
\text { in her "about } \\
\text { me" section, } \\
\text { however she } \\
\text { does make } \\
\text { specific mention } \\
\text { of fan-favourite } \\
\text { fantasy series } \\
\text { Game of } \\
\text { Thrones, } \\
\text { referencing } \\
\text { Cersei and } \\
\text { calling herself } \\
\text { "Queen Claudia" }\end{array}$ \\
\hline $\begin{array}{l}\text { Facebook (Direct } \\
\text { link) }\end{array}$ & $\begin{array}{l}\text { Claudia Tan Ann } \\
\text { Zhi }\end{array}$ & $\begin{array}{l}\text { Image is a full- } \\
\text { colour } \\
\text { photograph of } \\
\text { Claudia sitting at } \\
\text { a table in a }\end{array}$ & $\begin{array}{l}\text { Wallpaper is a } \\
\text { woman wearing } \\
\text { a short red dress } \\
\text { viewed from } \\
\text { behind standing }\end{array}$ & None included. \\
\hline
\end{tabular}




\begin{tabular}{|c|c|c|c|c|}
\hline & & $\begin{array}{l}\text { restaurant } \\
\text { setting. Main } \\
\text { colour choices } \\
\text { are blue (her } \\
\text { denim jacket) } \\
\text { and red (the } \\
\text { vinyl seat behind } \\
\text { her) }\end{array}$ & $\begin{array}{l}\text { in the centre of a } \\
\text { cityscape. }\end{array}$ & \\
\hline $\begin{array}{l}\text { Twitter } \\
\text { (Unlinked) }\end{array}$ & $\begin{array}{l}\text { @ claudiaoverher } \\
\text { e }\end{array}$ & $\begin{array}{l}\text { Avatar is a } \\
\text { photograph of } \\
\text { the author } \\
\text { standing in front } \\
\text { of a grey wall } \\
\text { with a trellis with } \\
\text { vines. The } \\
\text { colours have } \\
\text { changed to more } \\
\text { subdued pink } \\
\text { (her top) and } \\
\text { blue (her shorts) }\end{array}$ & $\begin{array}{l}\text { Wallpaper is a } \\
\text { woman wearing } \\
\text { a short red dress } \\
\text { viewed from } \\
\text { behind standing } \\
\text { in the centre of a } \\
\text { cityscape. }\end{array}$ & $\begin{array}{l}\text { \#slayqueenclaudi } \\
\text { a }\end{array}$ \\
\hline $\begin{array}{l}\text { Goodreads } \\
\text { (Unlinked) }\end{array}$ & Claudia Tan & $\begin{array}{l}\text { Avatar is a } \\
\text { photograph of } \\
\text { Claudia in a blue } \\
\text { jacket (identical } \\
\text { to the one worn } \\
\text { in her Wattpad } \\
\text { image) against a } \\
\text { body of water. }\end{array}$ & None & \\
\hline
\end{tabular}

*Direct Link indicates profiles that are directly linked to on Wattpad profile

Findability: Tan's Facebook account was linked to her Wattpad account, however, that was linked with her Instagram. This may have allowed fans some 
AUTHORS ONLINE: STRATEGIES FOR DIGITAL SELF-PROMOTION

limited ability to follow her on her various accounts, but her Facebook account was not entirely open unless you became "friends". While her visual identity was not exactly consistent, this would help her fans to find and recognize her.

Performance of Identity: Gender, Genre, Race (Visible Minorities), Thematic Ties to Novels, Interests

Tan was a self-proclaimed chick-lit author, tagging her own work as a part of this category on Wattpad. Her biography referenced the popular Game of Thrones series, rather than including personal information about herself.

\section{Impact of Special Events}

Watty winner in 2015 (for her romance Perfect Addiction) and 2016.

For the purposes of this study, only the most recent win will be included.:

Perfect Redemption won people's choice 2016, Perfect Illusion won Best Fiction, also in 2016

\begin{tabular}{|l|l|l|}
\hline $\begin{array}{l}\text { Date of Award } \\
\text { announcement on } \\
\text { Comment board }\end{array}$ & $\begin{array}{l}\text { Number of fan comments in the } \\
\text { month before award } \\
\text { announcement }\end{array}$ & $\begin{array}{l}\text { Number of fan comments in the } \\
\text { month following award } \\
\text { announcement }\end{array}$ \\
\hline December 25, 2016 & 84 & 94 \\
\hline
\end{tabular}

The discussion on Tan's page grew to 94 from 84 comments in the month preceding her Watty award announcement on December 25, 2016. 
Her comment board contained 14 congratulatory comments following the award announcement; however, she didn't reply to any of them individually, favouring many announcements encouraging her fans to vote for her novels and spam the voting boards so they would win. She used unifying terms in her posts linking herself with her fans as if they are on one team called the "Dia-hards" for example "I have faith in my Dia-hard army".

Leading up to the award announcement, Tan made many announcements asking her fans to vote for her works that were up for awards. These announcements included links.

\section{Interpersonal Factors}

\begin{tabular}{|c|c|c|c|c|c|c|c|c|c|}
\hline 1 & 2 & 3 & 4 & 5 & 6 & 7 & 8 & 9 & 10 \\
\hline $\begin{array}{l}\text { Number of } \\
\text { author } \\
\text { posts in } \\
\text { the month } \\
\text { before an } \\
\text { award } \\
\text { announce } \\
\text { ment } \\
\text { (including } \\
\text { the award } \\
\text { announce } \\
\text { ment } \\
\text { itself) }\end{array}$ & $\begin{array}{l}\text { Total } \\
\text { Number of } \\
\text { fan } \\
\text { comments } \\
\text { in the } \\
\text { month } \\
\text { before } \\
\text { award } \\
\text { announce } \\
\text { ment }\end{array}$ & $\begin{array}{l}\text { Number of } \\
\text { fan } \\
\text { comments } \\
\text { in month } \\
\text { before } \\
\text { award } \\
\text { announce } \\
\text { ment with } \\
\text { replies } \\
\text { from the } \\
\text { author }\end{array}$ & $\begin{array}{l}\text { Number of } \\
\text { author } \\
\text { posts in } \\
\text { the month } \\
\text { following } \\
\text { an award } \\
\text { announce } \\
\text { ment } \\
\text { (not } \\
\text { including } \\
\text { direct } \\
\text { replies to } \\
\text { comments } \\
\text { ) }\end{array}$ & $\begin{array}{l}\text { Total } \\
\text { number of } \\
\text { fan } \\
\text { comments } \\
\text { in the } \\
\text { month } \\
\text { following } \\
\text { award } \\
\text { announce } \\
\text { ment }\end{array}$ & $\begin{array}{l}\text { Number of } \\
\text { fan } \\
\text { comments } \\
\text { with } \\
\text { replies } \\
\text { from the } \\
\text { author } \\
\text { following } \\
\text { the award } \\
\text { announce } \\
\text { ment (not } \\
\text { including } \\
\text { direct } \\
\text { replies to } \\
\text { comments } \\
\text { ) }\end{array}$ & $\begin{array}{l}\text { Number of } \\
\text { author } \\
\text { replies } \\
\text { (from the } \\
\text { month } \\
\text { before and } \\
\text { after } \\
\text { award } \\
\text { announce } \\
\text { ment) that } \\
\text { generated } \\
\text { a second } \\
\text { reply } \\
\text { from the } \\
\text { initial } \\
\text { commente } \\
\text { r }\end{array}$ & $\begin{array}{l}\text { Nature of } \\
\text { conversati } \\
\text { on that } \\
\text { generated } \\
\text { follow-up } \\
\text { reply }\end{array}$ & $\begin{array}{l}\text { Nature of } \\
\text { author } \\
\text { post } \\
\text { content } \\
\text { before } \\
\text { award } \\
\text { announce } \\
\text { ment }\end{array}$ & $\begin{array}{l}\text { Nature of } \\
\text { author } \\
\text { post } \\
\text { content } \\
\text { following } \\
\text { award } \\
\text { announce } \\
\text { ment }\end{array}$ \\
\hline 27 & 94 & 26 & 6 & 93 & 7 & 0 & $\mathrm{~N} / \mathrm{a}$ & $\begin{array}{l}0, \\
1, \\
1 / 5\end{array}$ & $\begin{array}{l}0, \\
1, \\
2,\end{array}$ \\
\hline
\end{tabular}




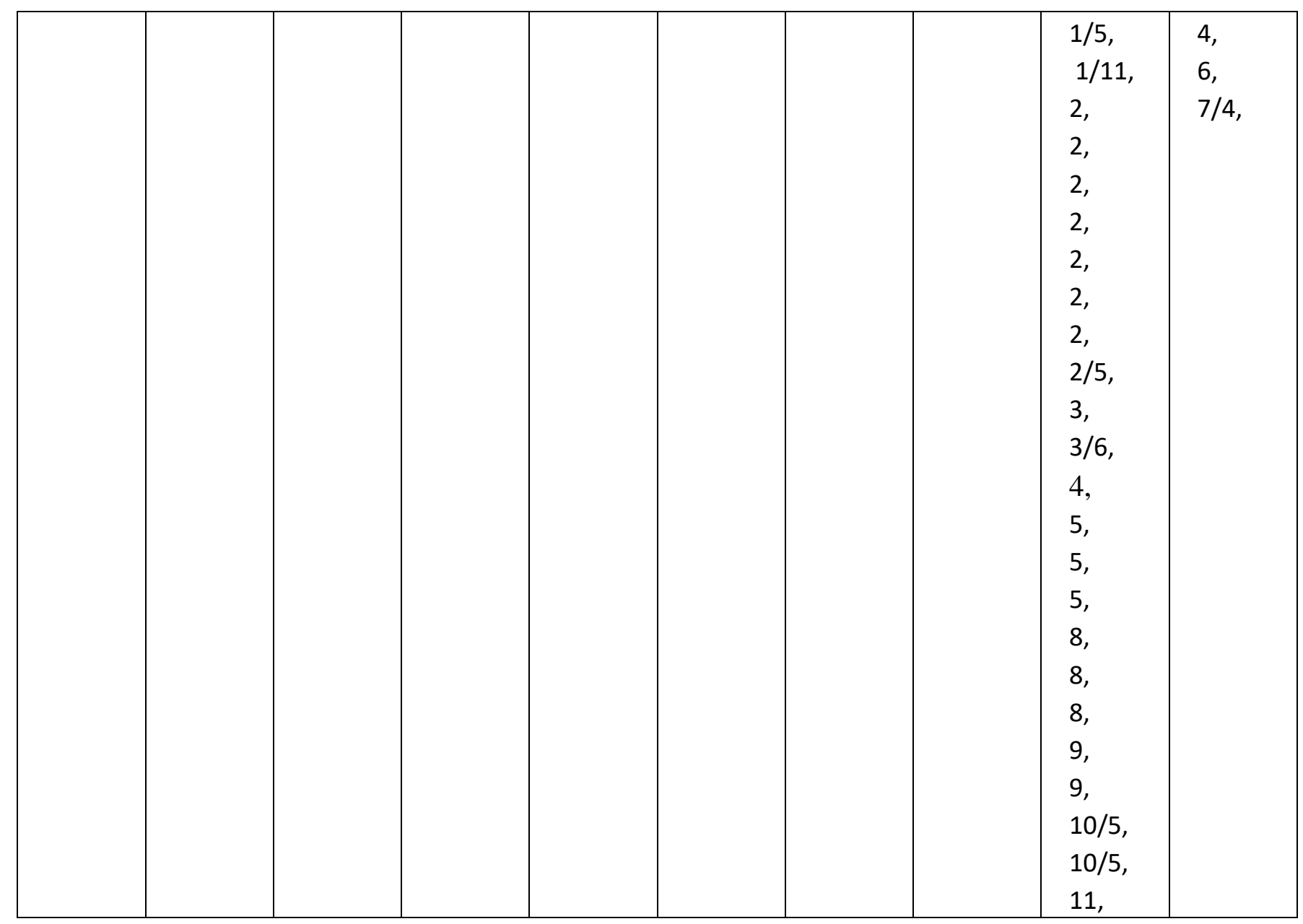

Tan focused her energy on creating announcements that teased about new releases, new chapters and works as well as promoting her other social channels which featured related content or play a part in her search for new cover art following her award announcement. She intermittently engaged directly with her fans, replying to nine percent of fan comments following her award announcement. More often she replied to fans who commented on her wall before 
AUTHORS ONLINE: STRATEGIES FOR DIGITAL SELF-PROMOTION

an awards announcement. However, the rate of replies during the voting phase was low. 


\section{Appendix C: Case Study Three: A.V. Geiger}

\section{Branding}

Name and Handles: Consistent name and handle across most channels.

\begin{tabular}{|c|c|c|c|c|}
\hline Social Platforms & $\begin{array}{c}\text { Name/Handle } \\
\text { on Each } \\
\text { Platform }\end{array}$ & Avatar Notes & $\begin{array}{l}\text { Wallpaper } \\
\text { Image Notes }\end{array}$ & Slogan Notes \\
\hline Wattpad & A.V. Geiger & $\begin{array}{l}\text { Image is a close- } \\
\text { cropped selfie, of } \\
\text { the author } \\
\text { against a neutral } \\
\text { background. }\end{array}$ & $\begin{array}{l}\text { Wallpaper is a } \\
\text { photograph in } \\
\text { black and white } \\
\text { of a woman } \\
\text { looking through } \\
\text { venetian blinds, } \\
\text { using her fingers } \\
\text { to draw them } \\
\text { more open. It is } \\
\text { evocative of a } \\
\text { suspenseful } \\
\text { atmosphere. }\end{array}$ & $\begin{array}{l}\text { Geiger does not } \\
\text { use any slogans, } \\
\text { but instead } \\
\text { continually } \\
\text { reference her } \\
\text { new status as a } \\
\text { "published } \\
\text { author" }\end{array}$ \\
\hline $\begin{array}{l}\text { Twitter (Direct } \\
\text { link) }\end{array}$ & @av_geiger & $\begin{array}{l}\text { Image is } \\
\text { identical to } \\
\text { Wattpad avatar }\end{array}$ & $\begin{array}{l}\text { Wallpaper is a } \\
\text { cropped section } \\
\text { of a book cover } \\
\text { of a Wattpad } \\
\text { publication. } \\
\text { (Follow me } \\
\text { back) }\end{array}$ & N/A \\
\hline
\end{tabular}

*Direct Link indicates profiles that are directly linked to on Wattpad profile 


\section{Visual Identity}

Avatar Notes: Image is a full-colour photograph of the author herself in all cases.

\section{Accompanying Images / Background Image:}

Slogans: None included

Findability: Twitter profile directly linked to Wattpad profile.

Performance of Identity: Gender, Genre, Race (Visible Minorities), Thematic Ties to Novels, Interests

Tan did not provide personal information regarding her interests in her biography aside from her Game of Thrones reference. She had chosen to use photograph avatars which are identical for her platforms. She had also chosen to use an image derived from her book covers as her background image for her Twitter header image.

\section{Impact of Special Events}

The Mermaid Hypothesis, Best Science Fiction - Wattys November 4, 2016.

\begin{tabular}{|l|l|l|}
\hline $\begin{array}{l}\text { Date of Award } \\
\text { Announcement }\end{array}$ & $\begin{array}{l}\text { Number of Comments in the } \\
\text { Month Before Award } \\
\text { Announcement }\end{array}$ & $\begin{array}{l}\text { Number of Comments in the } \\
\text { Month Following Award } \\
\text { Announcement }\end{array}$ \\
\hline November 4, 2016 & 15 & 21 \\
\hline
\end{tabular}


The discussion on Geiger's page grew to 21 from 15 comments in the month preceding her Watty award announcement on November 4, 2016. Prior to her award announcement, Geiger's outreach focused on changes to works that were already posted, a newsletter welcoming new followers with details about the works in her repertoire, promoting a new book release, a reminder to fans to please vote for her work enrolled in contests and promoting a special Wattpad event. Writing contests and Wattpad special events were two ways built into the platform that provided opportunities for authors to gain visibility.

Her comment board contained 14 congratulatory messages, but most importantly she used the expanded exposure to her benefit, creating a story for her readers to coincide with a Halloween writing contest, and joining a secondary contest shortly following her Watty win. Geiger's strategy for outreach following her award was to push out new content (a new chapter of an already-posted workin-progress), to announce an upcoming published work and to introduce a promotional offer that incentivized Wattpad followers who had previously read her work at no cost (on Wattpad) to purchase a professional and newly edited paperback edition. In this example she was both rewarding her fans and securing sales numbers for her book's release. 
Geiger's response rate to her fans does drop following her awards announcement; however, her updates to her fans increased. These updates included thanking her fans for supporting her goals in terms of the awards (thanking fans for voting) and asking them to support her professional goals, including posts about her newly published works, and promotional offers that reward fans from Wattpad who had read her unedited work for free. She also participated in promotional events for new Wattpad writers.

\begin{tabular}{|c|c|c|c|c|c|c|c|c|c|}
\hline 1 & 2 & 3 & 4 & 5 & 6 & 7 & 8 & 9 & 10 \\
\hline $\begin{array}{l}\text { Total } \\
\text { number } \\
\text { of author } \\
\text { posts in } \\
\text { the month } \\
\text { before an } \\
\text { award } \\
\text { announce } \\
\text { ment }\end{array}$ & $\begin{array}{l}\text { Total } \\
\text { Number } \\
\text { of fan } \\
\text { comment } \\
\mathbf{s} \text { in the } \\
\text { month } \\
\text { before } \\
\text { award } \\
\text { announce } \\
\text { ment }\end{array}$ & 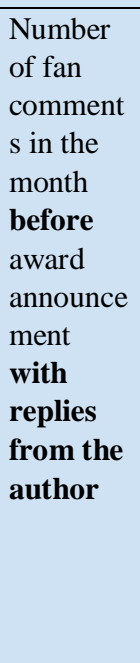 & 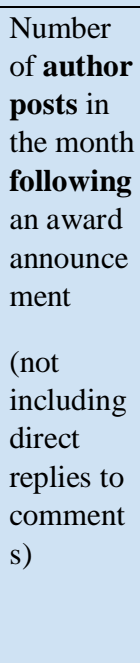 & $\begin{array}{l}\text { Total } \\
\text { number } \\
\text { of fan } \\
\text { comment } \\
\mathbf{s} \text { in the } \\
\text { month } \\
\text { following } \\
\text { award } \\
\text { announce } \\
\text { ment }\end{array}$ & $\begin{array}{l}\text { Number } \\
\text { of fan } \\
\text { comment } \\
\text { s with } \\
\text { replies } \\
\text { from the } \\
\text { author } \\
\text { following } \\
\text { the award } \\
\text { announce } \\
\text { ment (not } \\
\text { including } \\
\text { direct } \\
\text { replies to } \\
\text { comment } \\
\text { s) }\end{array}$ & 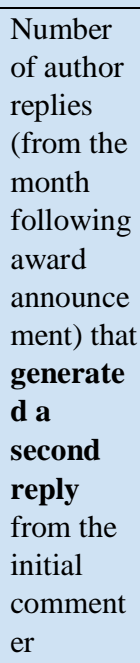 & $\begin{array}{l}\text { Nature of } \\
\text { conversa } \\
\text { tion that } \\
\text { generated } \\
\text { follow-up } \\
\text { reply }\end{array}$ & $\begin{array}{l}\text { Nature of } \\
\text { author } \\
\text { post } \\
\text { content } \\
\text { before } \\
\text { award } \\
\text { announc } \\
\text { ement }\end{array}$ & $\begin{array}{l}\text { Nature of } \\
\text { author } \\
\text { post } \\
\text { content } \\
\text { following } \\
\text { award } \\
\text { announc } \\
\text { ement }\end{array}$ \\
\hline 4 & 15 & 14 & 11 & $\begin{array}{l}21 \\
(14 \\
\text { congrat } \\
\text { ulatory } \\
\text { messag } \\
\text { es) }\end{array}$ & 12 & 7 & $\begin{array}{l}0, \\
3, \\
3, \\
3, \\
7, \\
8,\end{array}$ & $\begin{array}{l}1, \\
3, \\
5, \\
9, \\
12,\end{array}$ & $\begin{array}{l}1, \\
2, \\
3, \\
4, \\
5, \\
8, \\
8, \\
8 / 5 / 9 / 1 \\
0 \\
13 / 5,\end{array}$ \\
\hline
\end{tabular}


AUTHORS ONLINE: STRATEGIES FOR DIGITAL SELF-PROMOTION

\section{Interpersonal Factors}

Geiger reached out to fans through Newsletter posts about new work and caught up with new fans on what she already had posted. She made connections with her fans who posted on her page, answering $93 \%$ of fan posts on her page before her award announcement and $57 \%$ following her award announcement. She also provided incentives for her fans to purchase her newly-published work that had been available for them for free on Wattpad in an unedited version through an announcement that contained both a publishing announcement and a promotional incentive. Her other posts were announcements about her involvement in a Wattpad-hosted writing contest with a request and links for fans to vote for her work, she also was involved in promotional events that promoted other authors.

The comments on the site's board that were congratulatory led to the highest number of follow-up responses from fans. Geiger consistently answered fans with effusive thanks, matching the level of excitement fans used in their initial outreach. 


\section{Appendix D: Case Study Four: Shaun Allen}

\section{Branding}

Name and Handles: Consistent name and handle across all channels.

\begin{tabular}{|c|c|c|c|c|}
\hline Social Platforms & $\begin{array}{c}\text { Name/Handle } \\
\text { on each } \\
\text { Platform }\end{array}$ & Avatar Notes & $\begin{array}{c}\text { Wallpaper } \\
\text { Image Notes }\end{array}$ & Slogan Notes \\
\hline Wattpad & $\begin{array}{l}\text { Shaun Allen } \\
\text { @ShaunAllen }\end{array}$ & $\begin{array}{l}\text { Author avatar is } \\
\text { a } 3 / 4 \text { portrait of } \\
\text { the author with } \\
\text { arms crossed in } \\
\text { front of his chest } \\
\text { and chin dropped } \\
\text { towards his chest } \\
\text { standing against } \\
\text { a wall with a } \\
\text { mural painted } \\
\text { with black angel } \\
\text { wings. }\end{array}$ & $\begin{array}{l}\text { Wallpaper image } \\
\text { is a cropped shot } \\
\text { with three of his } \\
\text { Wattpad works } \\
\text { (Red Queen, And } \\
\text { the Meek Shall } \\
\text { Walk, and Sin) }\end{array}$ & $\begin{array}{l}\text { No slogans } \\
\text { appear on } \\
\text { Allen's profile } \\
\text { but the inclusion } \\
\text { of a quote from } \\
\text { his cover is } \\
\text { clearly tied to his } \\
\text { work. } \\
\text { He also includes } \\
\text { a list of } \\
\text { television and } \\
\text { comic series he } \\
\text { has worked on } \\
\text { since joining } \\
\text { Wattpad. }\end{array}$ \\
\hline $\begin{array}{l}\text { Instagram } \\
\text { (Direct link) }\end{array}$ & singularityspoint & $\begin{array}{l}\text { Image is a close- } \\
\text { cropped } \\
\text { photograph of } \\
\text { the author } \\
\text { against a sunset }\end{array}$ & N/A & N/A \\
\hline $\begin{array}{l}\text { Twitter (Direct } \\
\text { link) }\end{array}$ & $\begin{array}{l}\text { Shaun Allen } \\
\text { @ singularityspoi } \\
\text { nt }\end{array}$ & $\begin{array}{l}\text { Image is } \\
\text { identical to } \\
\text { Wattpad avatar: } \\
\text { Author avatar is } \\
\text { a } 3 / 4 \text { portrait of } \\
\text { the author with }\end{array}$ & $\begin{array}{l}\text { Image is a very } \\
\text { close-up } \\
\text { photograph of a } \\
\text { book cover with } \\
\text { the quote "There } \\
\text { is darkness and }\end{array}$ & $\begin{array}{l}\text { \#Wattys winner, } \\
\text { Wattpad star }\end{array}$ \\
\hline
\end{tabular}




\begin{tabular}{|c|c|c|c|c|}
\hline & & $\begin{array}{l}\text { arms crossed in } \\
\text { front of his chest } \\
\text { and chin dropped } \\
\text { towards his chest } \\
\text { standing against } \\
\text { a wall with a } \\
\text { mural painted } \\
\text { with black angel } \\
\text { wings. }\end{array}$ & $\begin{array}{l}\text { madness in each } \\
\text { of us. We must } \\
\text { do battle with } \\
\text { our own } \\
\text { demons" }\end{array}$ & \\
\hline $\begin{array}{l}\text { Facebook (Direct } \\
\text { link) }\end{array}$ & $\begin{array}{l}\text { Shaun Allen } \\
\text { Author } \\
\text { @Singularityspoi } \\
\text { nt }\end{array}$ & & $\begin{array}{l}\text { Wallpaper image } \\
\text { is a full image } \\
\text { with three of his } \\
\text { Wattpad works } \\
\text { (Red Queen a } \\
\text { Wattpad } \\
\text { FairyTtale } \\
\text { Community's } \\
\text { Retelling Awards } \\
\text { FCRAs Winning } \\
\text { Story, And the } \\
\text { Meek Shall Walk, } \\
\text { and Sin (The full } \\
\text { version of the } \\
\text { cropped } \\
\text { wallpaper image } \\
\text { chosen for } \\
\text { Wattpad profile) }\end{array}$ & N/A \\
\hline $\begin{array}{l}\text { Snapchat (Direct } \\
\text { link) }\end{array}$ & shaun_allen13 & $\begin{array}{l}\text { Image is a } \\
\text { cartoon avatar } \\
\text { including the } \\
\text { head alone, with } \\
\text { dark, short hair } \\
\text { and a playful, } \\
\text { winking } \\
\text { expression. }\end{array}$ & N/A & N/A \\
\hline
\end{tabular}

*Direct Link indicates profiles that are directly linked to on Wattpad profile 


\section{Visual Identity}

Avatar Notes: Allen used one avatar image across Wattpad, Facebook and Instagram, but the Instagram avatar is an anomaly.

Accompanying Images / Background Image: Background images for Wattpad and Facebook both included cover images from three of his Wattpad titles, including Watty winner Sin and Wattpad Fair Tale Community's Retelling Awards FCRAs Winning Story Red Queen. Twitter wallpaper image is a cropped photograph of a quote from the cover of one of Allen's works

Slogans: No slogans are included in the imagery related to Allen's profiles.

Findability: Allen had connected his Instagram, Facebook, Twitter and Snapchat platforms to his Wattpad account with direct links making it simple to click on any of these links to find him elsewhere.

\section{Performance of Identity: Gender, Genre, Race (Visible Minorities), Thematic Ties to Novels, Interests}

Allen's titles Wings and Icarus Wings both featured black wings as cover images. His chosen avatar closely echoed the visuals associated with these works. His biography included something of a curriculum vitae with writing that was unrelated to what was widely available on Wattpad including his screen and graphic novel writing experience gained since joining Wattpad. 
AUTHORS ONLINE: STRATEGIES FOR DIGITAL SELF-PROMOTION

Sin, Wattys 2016, The Red Queen, the Fairy Tale Community's 2016 Retelling

Awards

*Due to limitations of the conversation board, no conversations were available to view his communication prior to his 2016 Watty win, so this research instead focused on his work, The Red Queen, which won The Fairy Tale Community's 2016 Retelling Awards.

\begin{tabular}{|l|l|l|}
\hline $\begin{array}{l}\text { Date of Award } \\
\text { Announcement }\end{array}$ & $\begin{array}{l}\text { Number of Fan Comments in } \\
\text { the Month Before Award } \\
\text { Announcement }\end{array}$ & $\begin{array}{l}\text { Number of Fan Comments in } \\
\text { the Month Following Award } \\
\text { Announcement }\end{array}$ \\
\hline December 18, 2016 & 11 & 15 \\
\hline
\end{tabular}

\section{Impact of Special Events}

Allen's fan activity increased to 15 fan posts on his conversation board from only 11 in the month before. Interestingly, his activity exploded following the announcement, as his posts increased to 37 from 25 posts in the month following his award. The types of posts he created also saw changes following the award, with new publications and collaborative projects as well as new chapters and teasers for new projects dominated his news.

Allen's posts in the month prior to his award included several posts about his newly-published work, Sin, for which he received a Watty. Allen also included links to interviews and reviews of his work and plugged new content and 
collaborations. His involvement in several collaborative projects simultaneously was not something that was tracked during initial research; however, it should be noted that he posted 16 times following his award announcement compared with four times before his win, suggesting that his win may have provided greater opportunities for inclusion in collaborative projects.

\section{Interpersonal Factors}

Allen's conversation board was dominated by updates about his upcoming work with frequent teasers, updates, and collaborative project updates. He posted no less than daily in the month following his award announcement. He thanked his fans on several occasions for their support, going so far as to dedicate a chapter in one of his works (see the fan comment thanking him for his dedication). With the number of new works posted, Allen kept his fans up-to-date on his interests and informed them about new contests that they maybe interested to enter themselves.

Allen also focused on replying to fans who posted to his page and replied to $90 \%$ of his fans before the award announcement and $80 \%$ of their posts following his award. Of these replies, six generated further conversation. The nature of the conversations that generated follow-up replies revolved around his work on Wattpad (including where to begin when looking for one book to read out of his offerings) 


\begin{tabular}{|c|c|c|c|c|c|c|c|c|c|}
\hline 1 & 2 & 3 & 4 & 5 & 6 & 7 & 8 & 9 & 10 \\
\hline $\begin{array}{l}\text { Total } \\
\text { number } \\
\text { of author } \\
\text { posts in } \\
\text { the month } \\
\text { before an } \\
\text { award } \\
\text { announce } \\
\text { ment }\end{array}$ & $\begin{array}{l}\text { Total } \\
\text { Number } \\
\text { of fan } \\
\text { comment } \\
\mathbf{s} \text { in the } \\
\text { month } \\
\text { before } \\
\text { award } \\
\text { announce } \\
\text { ment }\end{array}$ & 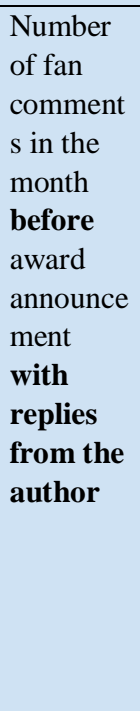 & 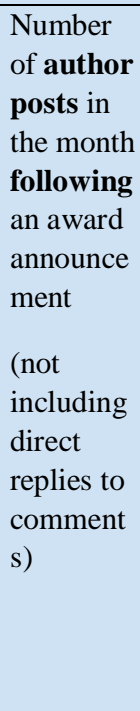 & $\begin{array}{l}\text { Total } \\
\text { number } \\
\text { of fan } \\
\text { comment } \\
\mathbf{s} \text { in the } \\
\text { month } \\
\text { following } \\
\text { award } \\
\text { announce } \\
\text { ment }\end{array}$ & $\begin{array}{l}\text { Number } \\
\text { of fan } \\
\text { comment } \\
\mathrm{s} \text { with } \\
\text { replies } \\
\text { from the } \\
\text { author } \\
\text { following } \\
\text { the award } \\
\text { announce } \\
\text { ment (not } \\
\text { including } \\
\text { direct } \\
\text { replies to } \\
\text { comment } \\
\text { s) }\end{array}$ & 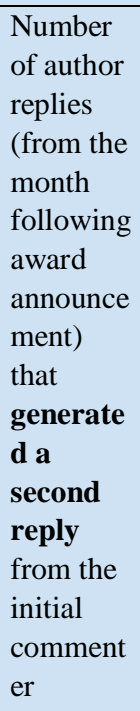 & $\begin{array}{l}\begin{array}{l}\text { Nature } \\
\text { of } \\
\text { conversa } \\
\text { tion that }\end{array} \\
\text { generated } \\
\text { follow-up } \\
\text { reply }\end{array}$ & 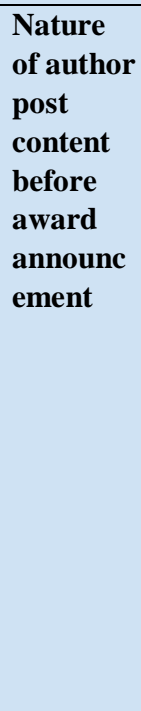 & $\begin{array}{l}\text { Nature } \\
\text { of author } \\
\text { post } \\
\text { content } \\
\text { following } \\
\text { award } \\
\text { announc } \\
\text { ement }\end{array}$ \\
\hline 25 & 11 & 10 & 37 & 15 & 12 & 6 & $\begin{array}{l}0 \\
0 \\
4 \\
9 \\
9 \\
1\end{array}$ & $\begin{array}{l}0, \\
0, \\
0, \\
1, \\
1, \\
1, \\
4, \\
4, \\
4, \\
5, \\
5, \\
9, \\
9, \\
9, \\
9, \\
10, \\
11, \\
14, \\
14, \\
16, \\
16, \\
16, \\
16,3\end{array}$ & $\begin{array}{l}0, \\
0, \\
0, \\
0, \\
1, \\
1 / 16, \\
1 / 16, \\
2, \\
2, \\
2, \\
2, \\
2, \\
2, \\
3, \\
3, \\
3, \\
9, \\
9, \\
9, \\
9 / 10, \\
16, \\
16,\end{array}$ \\
\hline
\end{tabular}


AUTHORS ONLINE: STRATEGIES FOR DIGITAL SELF-PROMOTION

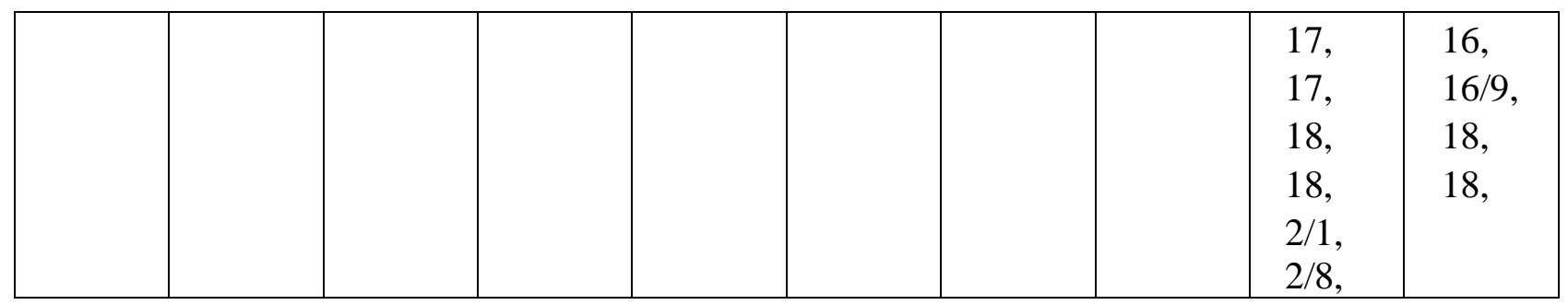




\section{Appendix E: Preliminary List of Authors}

\section{Legend}

Author used for sample analysis is highlighted in blue,

Authors ineligible due to limited information availability are highlighted in purple,

Authors ineligible due to lack of awards or due to name irregularities are highlighted in light grey,

Verified authors are in bold.

\section{Table 4}

\section{Wattpad Authors Listed by Highest Number of Followers}

\begin{tabular}{|c|c|c|c|c|c|c|c|c|c|c|}
\hline $\begin{array}{c}\text { Author } \\
\text { Name }\end{array}$ & $\begin{array}{c}\text { Wattpad } \\
\text { Handle }\end{array}$ & Country & Age & Gender & Genre(s) & $\begin{array}{c}\text { Date } \\
\text { Joined } \\
\text { Wattpad }\end{array}$ & $\begin{array}{l}\text { Number of } \\
\text { Followers }\end{array}$ & $\begin{array}{c}\text { \# titles } \\
\text { published } \\
\text { on } \\
\text { Wattpad }\end{array}$ & $\begin{array}{c}\text { Award } \\
\text { Winning } \\
\text { titles }\end{array}$ & Other awards \\
\hline $\begin{array}{l}\text { Anna } \\
\text { Todd }\end{array}$ & $\begin{array}{l}\text { imaginat } \\
\text { or1D }\end{array}$ & U.S.A. & N/A & Female & $\begin{array}{l}\text { Young } \\
\text { adult, } \\
\text { Romance, } \\
\text { fanfiction }\end{array}$ & $\begin{array}{l}\text { Jan. 19, } \\
2013\end{array}$ & $1.3 \mathrm{M}$ & 18 & & Wattpad Star \\
\hline $\begin{array}{l}\text { Isabelle } \\
\text { Ronin } \\
\end{array}$ & $\begin{array}{l}\text { isabeller } \\
\text { onin }\end{array}$ & Canada & N/A & Female & & $\begin{array}{l}\text { June 15, } \\
2014\end{array}$ & $839 \mathrm{~K}$ & 5 & & Wattpad Star \\
\hline $\begin{array}{l}\text { Gaby } \\
\text { Cabezut }\end{array}$ & $\begin{array}{l}\text { gabycabe } \\
\text { zut }\end{array}$ & Mexico & N/A & Female & Romance & $\begin{array}{l}\text { Nov. 2, } \\
2011\end{array}$ & $539 \mathrm{~K}$ & 24 & & $\begin{array}{l}\text { Wattpad Star } \\
\text { Wattpad } \\
\text { Ambassador }\end{array}$ \\
\hline $\begin{array}{l}\text { Lindsey } \\
\text { Summers }\end{array}$ & $\begin{array}{l}\text { DoNotMi } \\
\text { crowave }\end{array}$ & N/A & N/A & Female & & $\begin{array}{l}\text { July 6, } \\
2012\end{array}$ & $258 \mathrm{~K}$ & 20 & & Wattpad Star \\
\hline $\begin{array}{l}\text { Claudia } \\
\text { Tan }\end{array}$ & $\begin{array}{l}\text { claudiaov } \\
\text { erhere }\end{array}$ & Malaysia & 20 & Female & $\begin{array}{l}\text { Romance, } \\
\text { Young } \\
\text { adult, } \\
\text { Contempor } \\
\text { ary }\end{array}$ & $\begin{array}{l}\text { Nov. } 4, \\
2014\end{array}$ & $164 \mathrm{~K}$ & 11 & $\begin{array}{l}\text { Perfect } \\
\text { Redemptio } \\
\mathrm{n}(2016 \\
\text { Watty) } \\
\text { Perfect } \\
\text { Addiction } \\
\text { (2015 }\end{array}$ & Wattpad Star \\
\hline
\end{tabular}


AUTHORS ONLINE: STRATEGIES FOR DIGITAL SELF-PROMOTION

\begin{tabular}{|c|c|c|c|c|c|c|c|c|c|c|}
\hline & & & & & & & & & $\begin{array}{l}\text { Watty) } \\
\text { Perfect } \\
\text { Illusion } \\
\text { (Fiction } \\
\text { Awards) } \\
\end{array}$ & \\
\hline $\begin{array}{l}\text { Rebecca } \\
\text { Sky }\end{array}$ & $\begin{array}{l}\text { RebeccaS } \\
\text { ky }\end{array}$ & Canada & 32 & Female & $\begin{array}{l}\text { Romance, } \\
\text { Young } \\
\text { adult, } \\
\text { fantasy }\end{array}$ & $\begin{array}{l}\text { May 2, } \\
2010\end{array}$ & $62.4 \mathrm{~K}$ & 4 & $\begin{array}{l}\text { The } \\
\text { Cheaters } \\
\text { Club (2014 } \\
\text { Watty) }\end{array}$ & Wattpad Star \\
\hline $\begin{array}{l}\text { Kelly Anne } \\
\text { Blount }\end{array}$ & $\begin{array}{l}\text { KellyAnn } \\
\text { eBlount }\end{array}$ & U.S.A. & N/A & Female & $\begin{array}{l}\text { Romance, } \\
\text { Adult, } \\
\text { Young } \\
\text { adult, } \\
\text { horror }\end{array}$ & $\begin{array}{l}\text { March 9, } \\
2014\end{array}$ & $59.2 \mathrm{~K}$ & 24 & $\begin{array}{l}\text { Captured } \\
(2014 \\
\text { Watty) }\end{array}$ & $\begin{array}{l}\text { Wattpad Star } \\
\text { Wattpad } \\
\text { Ambassador }\end{array}$ \\
\hline Rachel & $\begin{array}{l}\text { knightsra } \\
\text { chel }\end{array}$ & & & Female & & & $222 \mathrm{~K}$ & 23 & & Wattpad Star \\
\hline $\begin{array}{l}\text { Brandon } \\
\text { Wong }\end{array}$ & $\begin{array}{l}\text { Brandon } \\
\text { Wong048 }\end{array}$ & Canada & 21 & Male & $\begin{array}{l}\text { Romance, } \\
\text { Young } \\
\text { adult }\end{array}$ & & $23.3 \mathrm{~K}$ & 8 & $\begin{array}{l}\text { Playing by } \\
\text { the Rules } \\
\text { (Watty } \\
\text { 2016) }\end{array}$ & Wattpad Star \\
\hline $\begin{array}{l}\text { Shaun } \\
\text { Allan }\end{array}$ & $\begin{array}{l}\text { ShaunAll } \\
\text { an }\end{array}$ & $\begin{array}{l}\text { United } \\
\text { Kingdom }\end{array}$ & N/A & Male & $\begin{array}{l}\text { Teen } \\
\text { fiction, } \\
\text { fantasy, } \\
\text { horror, } \\
\text { Young } \\
\text { Adult } \\
\end{array}$ & $\begin{array}{l}\text { June 21, } \\
2011\end{array}$ & $22.5 \mathrm{~K}$ & 39 & $\begin{array}{l}\text { Sin (2016 } \\
\text { Watty) }\end{array}$ & Wattpad Star \\
\hline
\end{tabular}




\section{References}

Bauwens, M. (2005). P2P and human evolution: Peer to peer as the premise of a new mode of civilization. Retrieved from http://www.altruists.org/static/files/P2P\%20and\%20Human\%20Evolution \%20(Michel\%20Bauwens).pdf

Baym, N. (2017). Personal connections in the modern age: Digital media and society series ( $2^{\text {nd }}$ ed.). Malden, MA: Polity Press.

Bold, M. (2016). The return of the social author: Negotiating authority and influence on Wattpad. Convergence. Retrieved from https://doi.org/10.1177/1354856516654459

Bowler, G. M. (2010). Netnography: A method specifically designed to study cultures and communities. The Qualitative Report, 15(5), 1270-1275. Retrieved from https://nsuworks.nova.edu/tqr/vol15/iss5/13

boyd, d. (2008). Why youth heart social network sites: the role of networked publics in teenage social life. In: Buckingham, D. (Ed), Youth, Identity, and Digital Media Volume (pp.119-142). Retrieved from https://www.danah.org/papers/WhyYouthHeart.pdf

Bruns, A. (2008). Blogs, Wikipedia, Second Life and beyond: From production to produsage. New York, NY: Peter Lang. 
AUTHORS ONLINE: STRATEGIES FOR DIGITAL SELF-PROMOTION

Bruns, A. (2007). Produsage: Towards a better product framework for user-led content creation. Proceedings Creativity \& Cognition, 6. Retrieved from https://eprints.qut.edu.au/6623/1/6623.pdf

Bruns, A. (2009). From prosumer to produser: Understanding user-led content creation. In Transforming Audiences Retrieved from http://www.cwanderson.org/wp-content/uploads/2009/08/ProdusageCreativity-and-Cognition-2007.pdf

Cerand, L. (2011). Social media for authors: Forever in search of buzz. The Practical Writer,5(1). Retrieved from https://www.pw.org/content/social_media_for_authors_forever_in_search _of_buzz

Davidson, J. (2009). Icon, iconography, iconology: Visual branding, banking and the case of the bowler hat. Accounting, Auditing \& Accountability Journal, 22(6), 883-906. doi:10.1108/09513570910980454

Davies, R. (2017). Collaborative paradigm and the transformation of publishing: The case of Wattpad. In: Graham, J. \& Gandini, A. (Eds.). Collaborative Production in the Creative Industries (pp. 51-67). doi:10.16997/book4.d.License

Fan Expo. (2018). Operating guidelines. Retrieved from https://www.fanexpocanada.com/content/dam/Informa/fanexpocanada/en/ 2018/Apply/FAN18FXC-SC-Operating-Guidelines-2018.pdf 
AUTHORS ONLINE: STRATEGIES FOR DIGITAL SELF-PROMOTION

Flahive, G. (2017). Digital self-promotion for the underdog author: creative opportunities and experimentation. Interscript Journal, 1(2), 23-42. doi:10.14324/111. 2398-4732.002. Retrieved from http://discovery.ucl.ac.uk/1556308/1/Flahive\%20Article.pdf

Foucault, M. (1977). What is an author? In: Bouchard DF (Ed.), Language, Counter-Memory, Practice. 124-127. Ithaca: Cornell University Press.

Gandini, A. (2016). Digital work: Self-branding and social capital in the freelance knowledge economy. Marketing Theory,16(1), 123-141. doi:10.1177/1470593115607942

Grunig, J. (2010). Dr. James Grunig on public relations - PRSA 2010 International Conference. PRSA National. Video presented at Public Relations Society of America Conference, Adams Morgan, Washington. Retrieved from https://www.youtube.com/watch?v=k6t70-pDsBg

Grunig, J. E. (2006). Furnishing the edifice: Ongoing research on public relations as a strategic management function. Journal of Public Relations Research. $18(2), 151-176$.

Grunig, J. E. \& Hunt, T. (1984). Managing public relations. New York: Holt, Rinehart \& Winston.

Gulbrandsen, T., \& Sine, N. (2011). The collaborative paradigm: Towards an invitational and participatory concept of online communication. Media, Culture \& Society. 33(7), 1095-1108. doi:10.1177/0163443711416066. 
AUTHORS ONLINE: STRATEGIES FOR DIGITAL SELF-PROMOTION

Gyrd-Jones, R., Merrilees, B., \& Miller, D. (2013). Revisiting the complexities of corporate branding: Issues, paradoxes, solutions. Journal of Brand Management, 20(7), 571-589. doi.org.ezproxy.lib.ryerson.ca/10.1057/bm.2013.1

Heusinkveld, Benders, \& van den Berg. (2009). From market sensing to new concept development in consultancies: The role of information processing and organizational capabilities. Technovation. 29, 509-516.

Jones, B. (2014). Fifty shades of exploitation: Fan labor and fifty shades of grey. Transformative Works and Cultures, 15. Retrieved from http://journal.transformativeworks.org/index.php/twc/article/view/501/422

Jones, E. E., \& Pittman, T. S. (1982). Toward a general theory of strategic selfpresentation. In J. Suls (Ed.), Psychological perspectives on the self (231261). Erlbaum: Hillsdale.

Kaplan, A., \& Haenlein, M. (2010). Users of the word, unite! The challenges and opportunities of social media. Business Horizons, 53(1), 59-68.

Kahn, R., \& Wilenski, R. (1995). A framework for distributed digital object services: Technical report in 95-01, Corporation for National Research Initiatives. Retrieved from http://www.cnri.reston.va.us/k-w.html (republished, with an additional introduction by the authors, as the keynote paper in a special issue on "Complex Digital Objects": International 
AUTHORS ONLINE: STRATEGIES FOR DIGITAL SELF-PROMOTION

Journal on Digital Libraries (2006) 6(2): 115-123. doi:10.1007/s00799005-0128-X

Kinberg, M. (2014). Market sensing as a tool for fiction authors. Journal of Marketing and Management, 1(1), 45-57.

Kozinets, R. (1998). On netnography: Initial reflections on consumer research investigations of cyberculture. In Joseph W. Alba \& J. Wesley Hutchinson (Eds.), NA - Advances in Consumer Research: 25, (pp. 366-371). Retrieved from http://acrwebsite.org/volumes/8180/volumes/v25/NA-25

Mitchell, W.J.T. (1994). Picture theory: Essays on verbal and visual representation. Chicago, Illinois: The University of Chicago Press.

Morrison, E. (2012). Why social media isn't the magic bullet for self-published authors. The Guardian. Retrieved from https://www.theguardian.com/books/2012/jul/30/tweet-about-cats-just$\underline{\text { write }}$

Muzellec, L., Lynn, T., \& Lambkin, M. (2012). Branding in fictional and virtual environments. European Journal of Marketing,46(6), 811-826. doi:10.1108/03090561211214618

Neuman, W.L. (2014). Social research methods: Qualitative and quantitative approaches ( $7^{\text {th }}$ ed.). Essex, England: Pearson Education Ltd. 
AUTHORS ONLINE: STRATEGIES FOR DIGITAL SELF-PROMOTION

Page, B. (2015). HarperCollins to close Authonomy. The Bookseller. Retrieved from http://www.thebookseller.com/news/harpercollins-closeauthonomy309711

Pham, A. (2010). Book publishers see their role as gatekeepers shrink. Los Angeles Times. Retrieved from http://www.latimes.com/business/la-figatekeepers-20101226-story.html

Phillips, A. (2014). Turning the page: The evolution of the book. London: Routledge.

Preece, J. (2000). Online communities: Designing usability, supporting sociability. Journal of Electronic Markets 2000, 10(4), 24.

Rinzler, A. (2011). The "New author platform" - What writers need to know. Forbes. Retrieved from https://www.forbes.com/sites/booked/2011/07/26/the-new-authorplatform-what-writers-need-to-know/\#bce2ee61f1d1

Rooney, M. (2014). Kindle direct publishing (KDP) - reviewed. The independent publishing magazine. Retrieved from http://www.theindependentpublishingmagazine.com/2014/02/ kindledirect- publishing-kdp-reviewed.html

Squires C. \& Murray, Ray P. (2013). The digital publishing communications circuit. In Book 2.0 3(1) (pp. 3-24). doi: 10.1386/btwo.3.1.3_1 
AUTHORS ONLINE: STRATEGIES FOR DIGITAL SELF-PROMOTION

Wattpad. (2017). Wattys 2017. Retrieved from https://wattys.wattpad.com/

Wattpad. (2018). Badges and profile symbols. Retrieved from https://support.wattpad.com/hc/en-us/articles/206167360-Badges-andProfile-Symbols

Wattpad. (2018). Wattpad Ambassadors. Retrieved from https://support.wattpad.com/hc/en-us/articles/200774324-Wattpad$\underline{\text { Ambassadors }}$

Wattpad. (2018). Verified Users. Retrieved from https://support.wattpad.com/hc/en-us/articles/200773154-Verified-Users

Wilkins, K. (2014). Writing resilience in the digital age. New Writing. 1(11), 6776. Retrieved from http://www.tandfonline.com.ezproxy.lib.ryerson.ca/doi/full/10.1080/1479 $\underline{0726.2013 .870579 ? \text { scroll=top\&needAccess }=\text { true }}$

Wong, R. (2018). Reviews and foreword. Retrieved from https://www.wattpad.com/187463141-playing-by-the-rules-reviews-andforeword

WordPress. (2018). About. Overview. Retrieved from https://wordpress.org/about/security/ 